\title{
Systematics of the southern African genus Ixia (Iridaceae: Crocoideae): 4. Revision of sect. Dichone
}

\author{
P. GOLDBLATT* and J.C. MANNING**
}

Keywords: Iridaceae, Ixia sect. Dichone, morphology, new species, southern Africa, taxonomy, winter rainfall zone

\author{
ABSTRACT
}

\begin{abstract}
The southern African genus Ixia L. comprises \pm 90 species from the winter-rainfall zone of the subcontinent. Ixia sect. Dichone (Salisb. ex Baker) Goldblatt \& J.C.Manning, one of four sections in the genus and currently including 10 species and three varieties, is distinguished by the following floral characters: lower part of the perianth tube filiform and tightly clasping the style; filaments not decurrent; upper part of the perianth tube short to vestigial; style branches involute-tubular and stigmatic only at the tips; and so-called subdidymous anthers. We review the taxonomy of the section, providing complete descriptions and distribution maps, and a key to the species. I. amethystina Manning \& Goldblatt is recognized to be a later synonym of I. brevituba G.J.Lewis. Most collections currently included under that name represent another species, here described as $I$. rigida. We recognize five additional species in the section: early summer-blooming $I$. altissima from the Cedarberg; $I$. bifolia from the Caledon District; $I$. flagellaris, a stoloniferous species from the Cedarberg; $I$. simulans from the western Langeberg; and I. tenuis from the Piketberg. We also raise to species rank I. micrandra var. confusa and var. minor, as $I$. confusa and $I$. minor respectively. Foliar and associated floral variation in the widespread $I$. scillaris has led us to recognize two new subspecies among its northern populations, broad leaved subsp. latifolia and the dwarfed, smaller flowered subsp. toximontana; subsp. scillaris is restricted to the immediate southwestern Cape, from Darling to Somerset West. Sect. Dichone now has 17 species and two subspecies.
\end{abstract}

\section{INTRODUCTION}

Restricted to the winter-rainfall zone of southern Africa, the genus Ixia L. comprises some 90 species divided among the four sections Dichone (Salisb. ex Baker) Goldblatt \& J.C.Manning, Ixia, Hyalis (Baker) Diels and Morphixia (Ker Gawl.) Pax (Goldblatt \& Manning 2011). Sect. Dichone, the smallest of these, comprised eight species and three varieties when last revised by Lewis (1962). In the later account of Ixia for Flora of southern Africa, De Vos (1999) followed Lewis's taxonomy closely but included the new species, I. collina, described by Goldblatt \& Snijman (1985), and altered the arrangement of species to place those with specialized, unilateral stamens at the end of the account. The most recent addition to the section, I. amethystina, was described by Manning \& Goldblatt (2006), but we have now discovered it to be conspecific with the type of I. brevituba. Most plants currently referred to I. brevituba in herbaria represent a separate species, described here as I. rigida.

Field work conducted since 1999 has resulted in the discovery of three sets of populations belonging to sect. Dichone that do not accord with any of the species currently recognized. We describe one of them from the Langeberg and allied to I. scillaris, as I. simulans, another from the Piketberg as I. tenuis and the third, evidently allied to the I. micrandra complex, as I. bifolia.

\footnotetext{
*B.A. Krukoff Curator of African Botany, Missouri Botanical Garden, P. O. Box 299, St. Louis, Missouri 63166, USA. E-mail: peter.goldblatt@mobot.org.

** Compton Herbarium, South African National Biodiversity Institute, Private Bag X7, Claremont 7735, South Africa / Research Centre for Plant Growth and Development, School of life Sciences, University of KwaZulu-Natal, Pietermaritzburg, Private Bag X01, Scottsville 3209, South Africa. E-mail: J.Manning@sanbi.org.za. MS. received: 2012-05-08.
}

Examination of living plants and herbarium specimens matching I. micrandra var. confusa and I. micrandra var. minor provide evidence that both are better regarded as separate species, which we treat as I. confusa and $I$. minor respectively. We identified two further undescribed species from the Cedarberg in herbaria, namely I. altissima, an early summer blooming species of uncertain affinities and I. flagellaris, allied to I. scillaris but the only stoloniferous species in the section.

We provide a complete review of sect. Dichone, expanding it to include 17 species, with I. scillaris subdivided into three subspecies.

\section{TAXONOMIC HISTORY}

As is the case for many Cape plants, the taxonomic history of sect. Dichone is complex. The genus Dichone (the meaning of the Greek translation, two tubes, might refer to the incompletely dehiscent anther thecae) was proposed without description by R.A. Salisbury in 1812 as 'Dichone crispa Laws. Cat.' for a plant known at the time as Ixia crispa L.f. (1782) but now treated as I. erubescens Goldblatt. The cryptic reference, 'Laws. Cat.', refers to an unpublished catalogue, perhaps merely a handwritten list, of plants evidently grown in the garden of the Scottish nurseryman, Peter Lawson, about which little appears to be known. C.F Ecklon (1827) likewise treated Ixia crispa and its immediate allies in a separate genus but for which he used the name Agretta, also without description. His species and combinations in Agretta are currently invalid. Ecklon intended to admit five species to his genus, one of which (A. stricta) is now $I$. stricta (Eckl. ex Klatt) G.J.Lewis, and another ( $A$. pallideflavens), which is now I. odorata Ker Gawl. (sect. Hyalis according to Goldblatt \& Manning 2011). Agretta stricta was referred by Klatt (1882) to his genus Tritonixia and the species was only transferred to Ixia (sect. 
Dichone) by Lewis in 1962. We have not identified Ecklon's A. grandiflora.

The name Dichone was validated by J.G. Baker (1877) as sect. Dichone Salisb. ex Baker of Tritonia, at which time it included T. scillaris (L.) Baker, T. trinervata Baker and T. undulata (Burm.f.) Baker (which he erroneously believed was an earlier synonym of Ixia crispa). T. undulata is correctly a species of Tritonia and is currently known by that name (Goldblatt \& Manning 2006). Ixia micrandra Baker (sect. Dichone) remained in Ixia on account of its actinomorphic flowers, although it has the filiform perianth tube, short anthers and involute style branches of Dichone. To add to the series of misunderstandings, Ixia retusa Salisb., described in 1796 by R.A. Salisbury but without a known type, was considered conspecific with what Ker Gawler (in Sims 1801) called I. scillaris. Later, Ker Gawler (1803) cited I. retusa under what he called I. polystachia (sic), which he then considered an earlier name for I. scillaris. The plate, t. 629 of Curtis's botanical magazine, is not, however, I. scillaris but is either I. confusa (G.J.Lewis) Goldblatt \& J.C.Manning or I. stricta (Eckl. ex Klatt) G.J.Lewis. It appears that Ker Gawler believed that $I$. retusa was a member of what we now call sect. Dichone. Plate t. 629 was later cited by Klatt (1882) under his combination Watsonia retusa, which like its basionym, I. retusa, is without a type. Both Lewis (1962) and De Vos (1999) excluded I. retusa from Ixia on the basis that the protologue is inadequate to identify the species. We concur.

The four species of sect. Dichone that occur in the western Karoo remained unknown until the early twentieth century, when collections of the three species Ixia curvata G.J.Lewis, I. rigida Goldblatt \& J.C.Manning, and I. trifolia G.J.Lewis were made by Rudolf Marloth in 1920. The first of the western Karoo species to be recognized, I. trifolia, was described by Lewis (1934), based on her own collection grown at Kirstenbosch Botanical Garden. In assigning the species to Ixia, Lewis evidently did not then realize that I. trifolia was closely allied to species of sect. Dichone, which at the time was included in Tritonia. Although she noted the unusual anther dehiscence via very narrow slits in I. trifolia, she regarded the species as belonging in sect. Euixia (i.e. sect. Ixia) and close to I. ovata (Andrews) Sweet, now I. abbreviata Houtt.

By 1954 Lewis regarded sect. Dichone as more closely allied to Ixia than to Tritonia and recommended its recognition as a separate genus (Lewis 1954: 100) because of its unique anther dehiscence. Later (Lewis 1962) she formally transferred sect. Dichone to Ixia, noting that the section was also unusual in the genus in its involute-tubular style branches and its distinctive anthers. She described I. brevituba G.J.Lewis and $I$. curvata in 1962, assigning Marloth's collection of what we here describe as I. rigida to her I. brevituba (Lewis 1962), which is typified by a 1929 collection made by Grant \& Theiler.

Time has provided new evidence for Lewis's conclusion that Dichone is more closely related to Ixia than to Tritonia. Species examined cytologically have the same basic chromosome number, $x=10$, and karyotype as other species of Ixia whereas Tritonia has $x=11$ (Goldblatt 1971a; De Vos 1982; Goldblatt \& Manning 2011). Ixia also has derived pollen grains with a single banded operculum (Goldblatt et al. 1991 and unpublished) whereas Tritonia has the plesiomorphic pollen grains of subfamily Crocoideae with a two-banded operculum. The two genera are clearly closely allied and available molecular studies (Goldblatt et al. 2006, 2008) indicate a sister relationship (with moderate bootstrap support, $80 \%$ ) between the one species each of Ixia (I. latifolia D.Delaroche) and Tritonia (T. disticha (Klatt) Baker) that were sequenced. Although Goldblatt \& Manning (1999) initially treated sect. Dichone as one of two sections of subg. Ixia they later reverted to Lewis's foursection classification of Ixia. There have been no molecular studies that shed light on the relationship of Ixia and Dichone but the unstated assumption implicit in the current taxonomy is that Dichone is nested within Ixia, hence its status as a section of that genus.

\section{MATERIALS AND METHODS}

Using standard methods of taxonomic investigation, we examined the holdings of Ixia in herbaria with significant southern African collections, BOL, K, MO, NBG, PRE, and SAM (acronyms following Holmgren et al. 1990). Our herbarium studies were accompanied by field investigation to determine variation within populations for some species, and their ecology, especially soil, aspect, and altitude.

\section{MORPHOLOGY}

Morphology: the vegetative morphology of sec. Dichone corresponds closely to that of other species of Ixia, with few exceptions. Leaves are plane and form a basal fan in most species but I. erubescens has crisped and undulate leaf margins, and leaves of I. scillaris are sometimes undulate, or rarely crisped in a few populations from the Piketberg, Pakhuis-Biedouw Mtns, and near Tulbagh. Leaves of I. minor (=I. micrandra var. minor) are terete to subterete or plane whereas those of I. micrandra are filiform, and both species usually have two or sometimes three leaves, the uppermost \pm entirely sheathing the lower part of the stem. I. bifolia, I. trinervata, and usually I. simulans also have two leaves, a basal foliage leaf and a second, largely to entirely sheathing, upper leaf. In I. trinervata the lanceolate foliage leaf is distinctive in having three \pm equally prominent veins. The lowermost leaf of I. simulans has one prominent vein and thickened margins, and the upper sheathing leaf is inserted above the stem base.

Flowers are produced in spikes typical of Crocoideae. The floral bracts are typical of Ixia, being membranous and \pm translucent, becoming dry with age. The outer of each bract pair usually has 3 prominent veins and 3 teeth but is occasionally 1-toothed, sometimes varying within a species but consistently so in I. rigida. Flowers of most species are predominantly pale to deep pink, sometimes mauve pink, but with a white to pale yellow throat often edged darker pink to mauve. The perianth is occasionally white in some individuals or populations 
of I. scillaris, notably in the Olifants River Valley populations of subsp. latifolia, but is purple in I. brevituba, the flowers of which have a dark centre and stamens. Flower orientation ranges from fully upright to half to fully nodding, thus facing to the side. Flowers of several species are scented. I. bifolia, I. confusa, I. stricta, and at least some populations of $I$. scillaris produce a roselike scent, and I. collina and I. rigida are also sweetly scented (Goldblatt \& Snijman 1985).

The perianth tube is usually described as filiform (or slender throughout) in sect. Dichone but the tepals are in fact fused for some distance beyond the lower filiform part of the tube. The length of the upper part of the tube is often so short as to be conveniently ignored but in Ixia altissima and I. rigida fully half the length of the tube is flared for \pm 2 and $1 \mathrm{~mm}$ respectively and the tube is thus clearly funnel-shaped. In I. trifolia the flared upper part of the tube is also developed to a significant degree. The walls of the slender, lower part of the tube always tightly clasp the style and the tube contains no nectar.

Although radial floral symmetry is the common, and by inference ancestral, condition in the group, flowers of Ixia collina, I. erubescens, I. simulans, I. scillaris, I. tenuis, and probably also I. flagellaris are weakly zygomorphic. The flowers in these species face sideways and are thus nodding, the tepals held more-or-less vertically, with the stamens unilateral and the anthers horizontal or drooping. At dehiscence the stamens in the nodding flowers of I. curvata and I. stricta are symmetrically arranged but become unilateral with age, evidently through gravity (De Vos 1999).

Filaments are usually free and filiform, and inserted at the mouth of the narrow part of the perianth tube. In some populations of Ixia trifolia the filaments are united basally for up to $0.7 \mathrm{~mm}$, or up to one fifth their length. Anthers are oblong to subrotund and slightly to markedly recurved above the base. Species from the Western Karoo typically have oblong anthers, 4-5 mm long, with the thecae \pm twice or more as long as wide, whereas those from the southwestern Cape below the Escarpment are characterized by their derived, short, suborbicular to broadly oblong anthers, $2-4 \mathrm{~mm}$ long and $<$ twice as long as wide. Several species within this group have unilateral stamens (I. collina, I. erubescens, I. simulans, and I. scillaris), with the thecae sharply acute at their bases. The filaments in these species are characteristically sharply recurved apically such that the thecae are held almost horizontally. Anthers in sect. Dichone dehisce from the base via narrow slits that do not open fully, a unique feature in the genus and family. Dehiscence is either \pm complete to the locule apex or incomplete and restricted to the lower third or half of the anther, as in I. scillaris. Anthers have been described as subdidymous (Lewis 1962), a term meant to imply the vestigial nature of the anther connective, which in sect. Dichone is a narrow, adaxial strip of tissue that continues from the apex of the filament to shortly below the anther apex. The two thecae are closely appressed without the usual welldeveloped sterile tissue of the connective on their adaxial surfaces.

The filiform style divides at the mouth of the narrow part of the perianth tube, thus at or shortly beyond the filament bases, and the style branches spread outwards, either \pm straight (e.g. I. bifolia, I. micrandra, I. trifolia) or falcate to recurved. The style branches are involute, with the margins rolled upward to form an enclosed, tubular channel open only at the apex, with the stigmatic surfaces restricted to the apices, which are often expanded or slightly bifurcate (e.g. in I. collina and I. micrandra).

The capsules are, as far as known, typical of Ixia (Goldblatt \& Manning 2011), as are the seeds, which have a smooth surface and an excluded vascular trace (Goldblatt et al. 2006; Goldblatt \& Manning 2011). Capsules are known for only a few species and we do not routinely include capsule features in the species descriptions below. Notably, however, the few available capsules of I. scillaris are \pm obovoid, possibly a distinguishing taxonomic feature.

\section{INFRASECTIONAL CLASSIFICATION}

No classification below sectional rank has until now been proposed for sect. Dichone. However, with 17 species, it seems useful to us to recognize two species groups, or series. We include species with radially symmetric flowers and either complete or incomplete anther dehiscence in ser. Euanthera, thus including the Cedarberg I. altissima, all western Karoo species, and several from the southwestern Cape. The anther thecae in ser. Euanthera dehisce conventionally along narrow slits for their entire length or almost so and are either \pm rounded or acute and recurved at the base. Species with mainly zygomorphic flowers and \pm unilateral stamens, I. stricta excepted, are included in ser. Dichone. The anthers in this group of species are mostly horizontal or pendent, acute and recurved at the base, and dehisce incompletely from below. No vegetative specializations consistently accompany these floral differences. Ser. Dichone, which is evidently monophyletic, is centred in the southwestern Cape below the Escarpment, with populations of I. scillaris ranging into northern Namaqualand and onto the Gifberg-Matsikamma Mtn complex. Ser. Euanthera is comparatively widespread.

\section{SYSTEMATICS}

Ixia sect. Dichone (Salisb. ex Baker) Goldblatt \& J.C.Manning in Bothalia 29: 63 (1999). Tritonia sect. Dichone Salisb. ex Baker: 163 (1877). Tritonia subg. Dichone (Salisb. ex Baker) Baker: 190 (1892). Tritonixia sect. Dichone (Salisb. ex Baker) Klatt: 357 (1882). Ixia subg. Dichone (Salisb. ex Baker) G.J.Lewis: 150 (1962). Type: I. scillaris L., lectotype here designated [Lewis: 159 (1962) and Goldblatt \& Manning: 63 (1999) listed I. crispa L. (or its synonym I. erubescens Goldblatt) as the type but only Tritonia undulata (with its presumed synonym I. crispa) and I. scillaris were included by Baker in the section when it was first validly described].

Dichone Lawson ex Salisb.: 320 (1812), nom. nud.

Agretta Eckl.: 23 (1827), nom. nud. 
Corm as in Ixia; stolons with a terminal cormlet produced in I. flagellaris. Leaves as in Ixia but sometimes only two and then lower with expanded blade and upper largely to entirely sheathing. Spike: outer bracts with 3(1) main veins acutely 3-toothed, 3-lobed, or 1-toothed. Flowers pink to magenta (rarely white), tepal bases white or yellow edged darker pink (blue-mauve with dark centre in I. brevituba), scented or unscented; perianth tube usually relatively short, filiform below and clasping style sometimes funnel-shaped with upper part flared. Stamens symmetrically disposed or unilateral and reclinate, filaments inserted at apex of narrow part of tube, filiform or flattened; anthers straight and linear to oblong or short and suborbicular, with vestigial connective, thecae fully or incompletely dehiscent, then splitting from base by narrow slits. Style dividing at mouth of tube opposite or just above base of filaments, branches filiform-tubular and involute, thus stigmatic only at apices, straight or falcate-recurved.

\section{Ser. Euanthera Goldblatt \& J.C.Manning, ser. nov.}

Flowers upright or nodding. Stamens symmetrically arranged (at least in bud and on opening, sometimes later by gravity unilateral in Ixia curvata); anthers straight, rounded at base, or recurved and \pm acute at base, dehiscing conventionally by longitudinal slits to reach apex or almost so. Style branches \pm straight or falcate. Type species: I. micrandra Baker.

10 spp., western half of the Cape floral region and western Karoo.

1. Ixia altissima Goldblatt \& J.C.Manning, sp. nov.

TYPE.-Western Cape, 3219 (Wuppertal): Gonna-

\section{Key to species of sect. Dichone}

1a Plants $0.9-1.2 \mathrm{~m}$ high; perianth tube funnel-shaped with flared upper portion $\pm 2 \mathrm{~mm}$ long and \pm as long as filiform lower half; style dividing opposite middle $1 / 3$ of anthers $\ldots \ldots \ldots \ldots \ldots \ldots \ldots \ldots \ldots \ldots \ldots \ldots \ldots \ldots \ldots \ldots \ldots$ altissima

1b Plants $0.9-1.5 \mathrm{~m}$ high; perianth tube cylindrical almost throughout, flared only in upper $0.5-1.0 \mathrm{~mm}$ if at all; style dividing opposite or just above bases of filaments:

2a Flowers radially symmetric, upright to half nodding; stamens erect with anthers parallel or diverging:

3a Perianth tube very short, $2.0-2.5 \mathrm{~mm}$ long; stem with short, stiffly erect lateral branches held close to main axis, each with up to 8

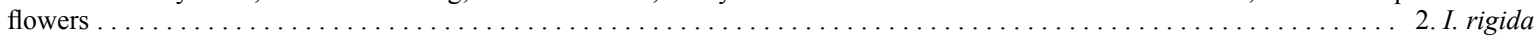
3b Perianth tube 2.3-6.0 mm long; stem simple or with 1(-several) suberect to spreading branches:

4a Leaves \pm terete or filiform, rarely more than $1 \mathrm{~mm}$ wide; corm tunics of fine fibres extending upward in a collar around the stem base: 5a Style branches straight and extending outward below anthers, 3-5 mm long; filaments filiform; outer floral bracts with 3 main

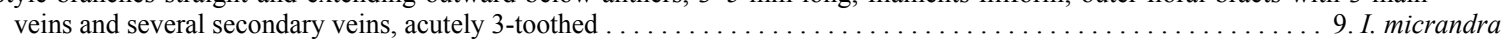

5 b Style branches falcate, recurved at tips, up to $2 \mathrm{~mm}$ long; filaments flattened and wider in middle; outer floral bracts with 3 main

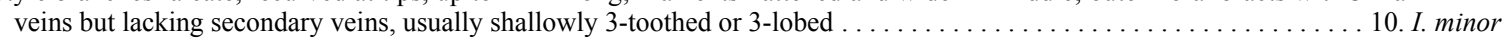

$4 \mathrm{~b}$ Basal and sometimes other leaves linear to sword-shaped or lanceolate, usually at least $1.5 \mathrm{~mm}$ wide, blades plane with main vein and sometimes multiple veins \pm equally prominent; corm tunics fine to coarse-textured, with or without fibrous collar around the stem base:

6a Anthers 4-5 mm long, oblong and > twice as long as wide; spike nodding in bud, becoming erect as flowers open:

7a Anthers yellow; perianth pink, tepals darker at base and yellow in throat; foliage leaves (2.5-)5-12 mm wide; style branches

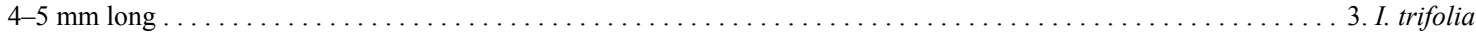

$7 \mathrm{~b}$ Anthers purple; perianth light purple with small dark centre; foliage leaves 1.5-2.0 mm wide; style branches up to 2 mm long ......... . . . . . . 4. . brevituba

$6 \mathrm{~b}$ Anthers $1.5-3.0 \mathrm{~mm}$ long, suborbicular to broadly oblong and $<$ twice as long as wide; spike erect in bud:

8a Leaves 2, basal leaf with expanded, \pm lanceolate blade, upper leaf entirely sheathing:

9a Basal leaf with $3 \pm$ equally prominent, thickened veins; style branches falcate to recurved (white drying \pm white); tepals $12-15 \times 6-8 \mathrm{~mm}$ when fully open; spike mostly $7-12$-flowered $\ldots \ldots \ldots \ldots \ldots \ldots \ldots \ldots \ldots \ldots \ldots \ldots$. trinervata $9 \mathrm{~b}$ Basal leaf with 1 prominent vein (translucent when alive, appearing raised when dry); style branches ascending, \pm straight (pink, often drying purple); tepals remaining slightly cupped, 12-14 ×5-7 mm; spike mostly 4-7-flowered ....... 7. I. bifolia 8 b Leaves $>2$, usually 3 to 5 , with no visible veins or only main vein prominent:

10a Leaves (3) 4 or 5, often drying at anthesis; foliage leaf blades lanceolate, mostly $4-9$ mm wide . . . . . . . . 11. I. stricta

10b Leaves (2)3 or 4; foliage leaf blades linear, mostly $1.5-4.0 \mathrm{~mm}$ wide $\ldots \ldots \ldots \ldots \ldots \ldots$. . . . . . . . . . . . . . . . . .

$2 \mathrm{~b}$ Flowers usually half to fully nodding, facing to side; stamens unilateral with anthers held horizontally or pendent:

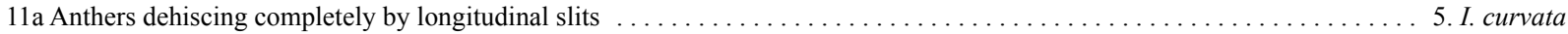

$11 \mathrm{~b}$ Anthers dehiscing by short slits from base to middle, not reaching apex:

12a Foliage leaf usually single, sometimes 2 (uppermost leaf \pm entirely sheathing), blade \pm linear, $1.0-4.5$ mm wide; flowers usually

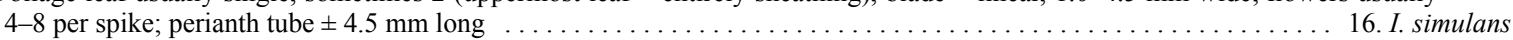

12b Foliage leaves 3-7, blades lanceolate to falcate, mostly 4-20 mm wide, or closely undulate and then only 2-4 mm wide; perianth tube $2.5-4.0 \mathrm{~mm}$ long:

13a Leaves 2-4(5) mm wide; corm tunics of fine, soft fibres; perianth tube $2-3 \mathrm{~mm}$ long:

14a Leaf margins strongly undulate and crisped; anthers $\pm 1.5 \mathrm{~mm}$ long

12. I. erubescens

14b Leaf margins plane; anthers 2-3 mm long:

15a Corms producing slender stolons from base, terminating in a single, large cormlet; anthers $\pm 3 \mathrm{~mm}$ long ...... 15. I. flagellaris

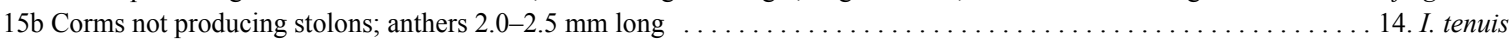

13b Leaves 4-25 mm wide and margins plane or sometimes undulate(-crisped), corm tunics of firm, medium-textured to coarse fibres; perianth tube $2.5-5.0 \mathrm{~mm}$ long:

16a Plants to $90 \mathrm{~cm}$ high, often branched, with branches held at right angles to main axis, becoming suberect distally; filaments expanded toward apex and becoming as wide as anthers; style branches widely flared at tips . . . . . . . . . . . . . 17. I. collina

16b Plants rarely more than $60 \mathrm{~cm}$ high, simple or branched, with branches ascending to suberect; filaments \pm uniformly filiform, $<1 / 2$ as wide as anthers; style branches not noticeably flared at tips $\ldots \ldots \ldots \ldots \ldots \ldots \ldots \ldots \ldots \ldots \ldots \ldots \ldots$. $\ldots \ldots \ldots$ scillar 
fontein, seep in sandstone ground among Kniphofia, 900 m, (-CB), 5 Dec. 2005, Pond 303 (NBG, holo.).

Plants $0.9-1.2 \mathrm{~m}$ high, stem surrounded at base by membranous cataphylls, simple or with 1-2 branches subtended by translucent, attenuate bracts and prophylls up to $8 \mathrm{~mm}$ long. Corm 15-18 $\mathrm{mm}$ diam., mature tunics not known, Leaves 4 , lower $3 \pm$ basal, reaching to \pm middle of stem, blades linear to linear-sword-shaped, (3-)4$10 \mathrm{~mm}$ wide, firm-textured, margins and midrib and often a pair of secondary veins thickened and hyaline (at least when dry), uppermost leaf largely sheathing. Spike erect, elongate, weakly flexuose, 14-20-flowered, lateral spikes 6-14-flowered; bracts dry, membranous, translucent, flecked with brown in upper half, outer \pm 7 $\mathrm{mm}$ long, usually with 3 prominent veins and 3-toothed, inner bracts \pm as long as outer or slightly shorter, 2-veined and 2-toothed. Flowers rotate, mauve-pink; perianth tube narrowly funnel-shaped, $\pm 4 \mathrm{~mm}$ long, filiform and clasping style below, flared in distal $\pm 2 \mathrm{~mm}$; tepals spreading, oblong-ovate, $12-13 \times \pm 4 \mathrm{~mm}$. Stamens symmetrically disposed, erect; filaments filiform, inserted just above narrow part of tube, $\pm 4 \mathrm{~mm}$ long, \pm white; anthers oblong, $\pm 3 \mathrm{~mm}$ long, erect, dehiscing fully by longitudinal slits, yellow. Style dividing opposite middle of anthers, branches $\pm 2 \mathrm{~mm}$ long, falcate, pale yellow, tubular, stigmatic apically, arching outward between or shortly overtopping anthers. Flowering time: Nov.-mid-Dec.

Distribution and habitat: Ixia altissima is known from two sites in the central and southern Cedarberg, from the Matjies River Nature Reserve and from Gonnafontein to the south (Figure 1). Plants grow along stream banks or in marshy seeps on sandstone derived soil, at the Gonnafontein site among Kniphofia plants. The habitat remains moist at least until December and possibly later into the summer. We suggest a conservation status for I. altissima of Rare (R), in light of its evident rarity, but we see no current threat to the species.

Diagnosis and relationships: Ixia altissima is a surprising plant, sometimes standing over $1 \mathrm{~m}$ in height and flowering late in the season, well into December. The anthers with vestigial connective and the involute style branches, stigmatic only at the tips, indicate its placement in sect. Dichone but the funnel-shaped

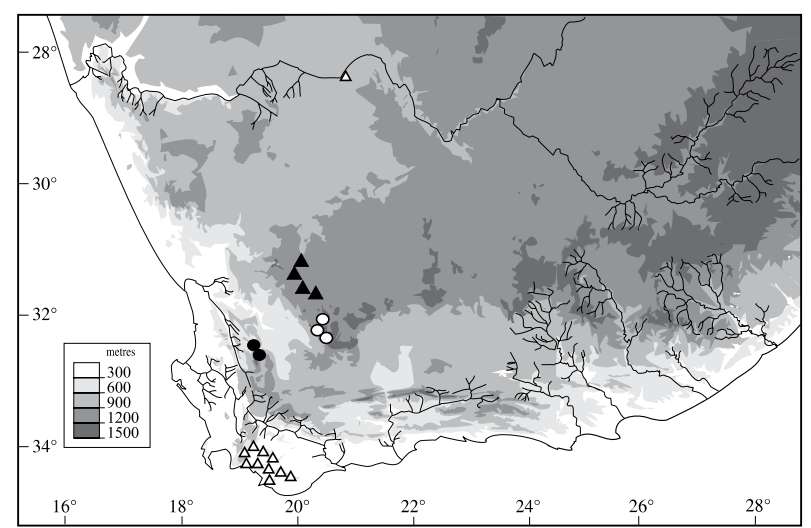

FIGURE 1.-Distribution of Ixia altissima, •; I. rigida, ○; I. curvata, $\mathbf{\Delta}$; and I. stricta, $\Delta$. perianth tube with the filaments inserted in the middle of the upper part of the tube is unusual for the section, most species of which have the tube virtually filiform throughout with the filaments inserted at the apex of the tube. The perianth tube, only $\pm 4 \mathrm{~mm}$ long, and the pale floral bracts are reminiscent of two Roggeveld Escarpment species, I. trifolia and I. rigida, the latter also flowering relatively late in the season, often in November. These species share relatively unspecialized, longitudinally dehiscent anthers. I. altissima seems most like $I$. rigida, also a tall plant, up to $600 \mathrm{~mm}$ high and sometimes flowering as late as November. The latter has flowers with a similarly funnel-shaped perianth tube $2-3 \mathrm{~mm}$ long and silvery translucent floral bracts, contrasting with the slightly longer perianth tube, $\pm 4 \mathrm{~mm}$ long, and shorter anthers, just $3 \mathrm{~mm}$ long, in I. altissima, which is also unusual in the section in having the style dividing opposite the middle of the anthers.

\section{Representative specimens}

WESTERN CAPE.-3219 (Wuppertal): Cedarberg, Matjies River Nature Reserve, stream bank, (-AD), 21 Nov. 1999, Low 5838 (NBG); Cedarberg, Gonnafontein, seep in sandstone ground among Kniphofia, 900 m, (CB), 3 Dec. 2000, Pond 256 (NBG)

\section{Ixia rigida Goldblatt \& J.C.Manning, sp. nov.}

TYPE.-Northern Cape, 3220 (Sutherland): \pm 38 $\mathrm{km}$ north of Sutherland to Middelpos, Farm Geelhoek, rocky dolerite slope with red clay soil, $3108 \mathrm{ft}$ [950 m], (-AB), 7 Sept. 2006, Goldblatt \& Porter 12796 (MO, holo.; NBG, iso.).

Plants (150-)300-600 mm high, stem usually with 2-3 \pm erect branches held close to axis, sheathed at base by firm, chestnut brown cataphylls, combining with old corm tunics and leaf bases to form collar around base. Corm 12-18 mm diam., tunics of firm, relatively hard fibres. Leaves (3-)5-7, lower (2-)3-6 with expanded blades, upper 1 or 2 leaves sheathing lower $1 / 3$ to middle of stem, blades sword-shaped to sub-linear, (3-)5-8 $\mathrm{mm}$ wide, main vein, margins, and often secondary vein pairs moderately thickened, hyaline when dry. Spike weakly flexuose, nodding in bud, mostly 8-15-flowered, lateral spikes with fewer flowers; bracts membranous, silver-translucent, $\pm 5.5-7.0 \mathrm{~mm}$ long, outer with prominent brown or purple central vein and few secondary veins not reaching upper margin, acute or with 2 obscure lateral lobes, inner 2-veined and acutely 2-toothed. Flowers rotate, pale pink, darker at tepal bases and \pm white in throat, sweetly rose-scented; perianth tube funnel-shaped, $\pm 2.5 \mathrm{~mm}$ long, filiform and clasping style in basal $1.5 \mathrm{~mm}$ or less, widely flared distally for up to 1 $\mathrm{mm}$; tepals spreading, ovate-oblong, $\pm 12(-15) \times 5(-7)$ $\mathrm{mm}$, obtuse. Stamens symmetrically arranged, erect; filaments inserted at mouth of narrow part of tube, filiform, $\pm 1.5(2.5) \mathrm{mm}$ long, \pm white; anthers oblong to linear, curved back at base, 3-4(5) mm long, slightly recurved basally, thecae subacute at base, dehiscing fully by longitudinal slits, yellow. Style dividing at base of filaments, branches \pm straight, 2.0-3.0(3.5) mm long, \pm filiform-tubular, stigmatic apically, white. Flowering time: Sept. to mid-Nov. Figure 2. 


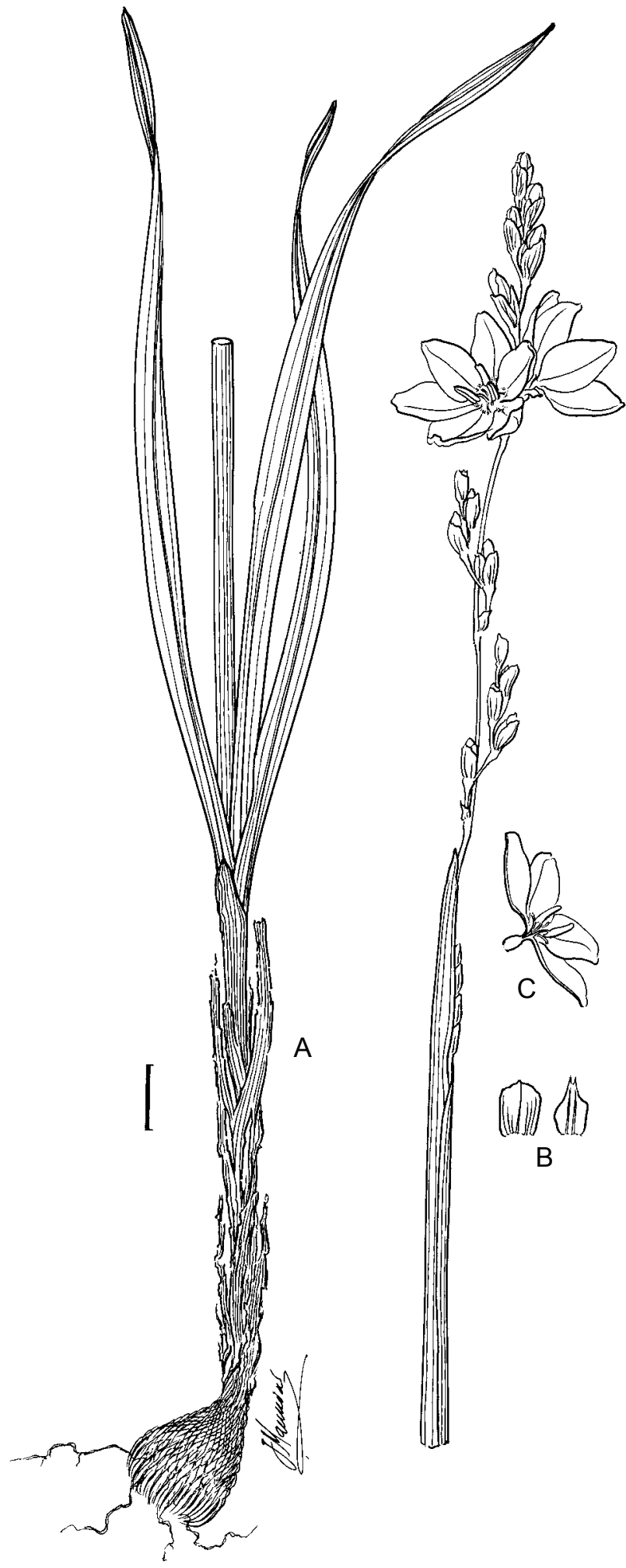

FIGURE 2.-Ixia rigida, Goldblatt \& Porter 12796 (NBG). A, whole plant; B, outer (left) and inner (right) bract; C, half flower. Scale bar: $10 \mathrm{~mm}$. Artist: John Manning.

Distribution and habitat: Ixia rigida is restricted to the Roggeveld, where it is known from the Escarpment edge on the Farms Fransplaas, Quaggasfontein, Uitkyk, Houdenbek and a short distance inland northwest of Sutherland on the Farm Geelhoek (Figure 1). Plants are restricted to dolerite outcrops and grow in rocky ground in the heavy red clay characteristic of this habitat. The first record of the species, made by Rudolf Marloth in 1920 and said to be from the 'Komsberg flats'[some distance south of Sutherland] may be erroneous, for I. rigida is otherwise unknown south of the town. The relatively few records show that the species is rare but plants often flower late, usually after mid-October on the escarpment edge, when relatively little collecting is done in the Roggeveld, so the present records may not fully reflect its range. There appears to be no imminent threat to its survival but at sites where we have seen the species, plants were heavily overgrazed and often do not set seed as a result. We tentatively suggest a conservation status of near-threatened, (NT).

Diagnosis and relationships: Ixia rigida is a distinctive species easily recognized by the moderately tall stem up to $600 \mathrm{~mm}$ high with 2-3 upright branches held close to the axis, and the silvery, translucent floral bracts subtending very short-tubed flowers, the tube up to 2.5 $\mathrm{mm}$ long with the narrow portion up to $\pm 1.5 \mathrm{~mm}$ long. Plants have up to seven leathery leaves with prominently thickened margins and main and secondary veins. I. rigida was known to Lewis (1962) from only a single specimen, which she associated with I. brevifolia and De Vos (1999) likewise misunderstood the species, citing specimens of I. rigida under the name I. brevifolia.

Although fairly uniform across its range the populations of Ixia rigida inland of the Roggeveld escarpment and flowering three to four weeks earlier than those along the edge of the escarpment, thus in September, have slightly larger flowers and less fibrotic leaves. Too little is known about I. rigida to assess the significance of this variation. We note, however, that the escarpment populations mostly have 6 or 7 leaves, typically 5-7 mm wide, tepals $\pm 12 \times 5 \mathrm{~mm}$, anthers $\pm 3 \mathrm{~mm}$ long, and style branches $\pm 2 \mathrm{~mm}$ long. The inland populations have 4 or 5 leaves, mostly $7-8 \mathrm{~mm}$ wide, tepals $\pm 14-16 \times 6-8$ $\mathrm{mm}$, slightly longer filaments, anthers $4(5) \mathrm{mm}$ long, and style branches $\pm 3.5 \mathrm{~mm}$ long. The bracts of the inland plants also stand out in their darker purple veins.

\section{Representative specimens}

NORTHERN CAPE.-3220 (Sutherland): Sutherland, Bo-Visrivier road, Farm Fransplaas, stony dolerite flats, (-AB), 19 Oct. 1995, Goldblatt \& Manning 10370 (MO); Roggeveld Escarpment, Farm Quaggasfontein, dolerite ridge near farm buildings, $4900 \mathrm{ft}[ \pm 1580 \mathrm{~m}]$, (-AB), 11 Oct. 2004, Goldblatt \& Porter 12667 (MO); Farm Uitkyk, Naaldegraskop, (-AD), 14 Nov. 1987, Goldblatt \& Manning 8645 (MO, NBG, PRE); Houdenhoek, Hoedenbek $4 \times 4$ trail, among dolerite boulders, $1387 \mathrm{~m}$, (-AD), 10 Oct. 2008, Clark \& Coombs 880 (NBG). Without precise locality and possibly an error: Komsberg flats, Oct. 1920, Marloth $9782 b$ (PRE).

3. Ixia trifolia G.J.Lewis in Flowering Plants of South Africa 14: t. 543 (1934); Lewis: 171 (1962); De Vos: 69 (1999). Type: South Africa, [Western Cape], Tweedside, cultivated in Cape Town, Sept. 1932, Lewis s.n. (Nat. Bot. Gard. 2706/32 in BOL, lecto., here designated; BOL!, K, PRE!, SAM!, isolecto.) [Lewis: 171 (1962) cited this number at BOL as the holotype but there are two sheets, hence our designation of a lectotype].

Plants mostly 150-300 mm high, stem usually with 1-2(-3) short branches, or simple, sheathed at base by short, firm, green cataphylls. Corm mostly 10-18 mm 
diam., tunics of coarse fibres, vertical elements often becoming claw-like ridges. Leaves 3 or 4(5), lower 2 or 3 with expanded blades, lanceolate to falcate, $1 / 2-2 / 3$ as long as stem, (2.5-)5-8(-12) mm wide, central vein and margins moderately thickened, upper 1(2) leaves sheathing lower $1 / 3-2 / 3$ of stem, without expanded blade. Spike weakly flexuose, inclined, drooping in bud, mostly 3-7-flowered; bracts membranous, translucent, 5-6 mm long, outer with prominent central vein, sometimes with 2 prominent secondary veins, acute or trilobed, inner slightly shorter than outer, 2-veined and 2-toothed. Flowers rotate, pale to deep pink (rarely mauve), yellow or white edged with darker pink at base of tepals, unscented; perianth tube funnel-shaped, 3.5-4.0 $\mathrm{mm}$ long, filiform in basal $2.5-3.0 \mathrm{~mm}$ and clasping style, flared in distal $1 \mathrm{~mm}$, tepals spreading, ovate-elliptic, obtuse to retuse, $12-15 \times 5.0-6.5 \mathrm{~mm}$. Stamens symmetrically arranged, erect, filaments inserted at mouth of narrow part of tube, 3-4 mm long, free or united basally for up to $0.7 \mathrm{~mm}$, filiform, \pm white, anthers oblong-linear, 3-4 mm long, yellow, thecae obtuse at base, dehiscing fully by longitudinal slits. Style dividing between base and lower $1 / 3$ of filaments, style branches $4-5 \mathrm{~mm}$ long, projecting between filaments, gently arched outward, filiform-involute, stigmatic apically, pale pink. Flowering time: mid-Aug. to late Sept. Figure 4E, F.

Distribution and habitat: Ixia trifolia has a relatively wide range, extending along the Roggeveld Escarpment from the Farm Uitkyk southward through the Klein Roggeveld to the Laingsburg Karoo as far west as Tweedside (Figure 3). Plants grow on stony clay ground in low, karroid scrub or mountain renosterveld. The flowers offer no nectar and are pollinated by pollen-collecting female bees. The anthophorine Amegilla spilostoma (Apidae) has been captured visiting flowers near Sutherland (Goldblatt \& Manning 2007) and we have also noted small hopliine beetles consistently visiting flowers at a population on the Farm Blesberg and clearly actively transferring pollen from flowers of one plant to those of another.

Diagnosis and relationships: Ixia trifolia is recognized by the combination of bright pink, rarely mauve flowers, white to yellow edged with dark pink in the centre, always held upright on inclined spikes, and two or three, relatively broad foliage leaves plus one (or two) more sheathing the stem. The specific epithet trifolia refers to the three foliage leaves, thus ignoring the presence of the upper, entirely sheathing leaf. Like other species of sect. Dichone from the Western Karoo, the style branches are slender and nearly straight and the anthers dehisce completely. Unique to this species in the section is that the filaments may be united basally for up to one quarter of their length, and the style is exserted up to 1.5 $\mathrm{mm}$ from the filiform part of the perianth tube. Ixia trifolia is perhaps most closely allied to I. brevituba, which has similarly oriented, upright flowers on an inclined spike but with narrower leaves, up to $1.5 \mathrm{~mm}$ wide and violet flowers darker in the centre. Both species stand out in the section in having the spikes drooping in bud.

Ixia trifolia is relatively common across its range but is poorly collected. The earliest collection of the species that we have found was made by Rudolf Marloth in 1920 at the top of Verlatekloof south of Sutherland although the type population was discovered at Tweedside near Touws River sometime before 1932. The type specimens comprise plants cultivated at Kirstenbosch Botanic Gardens under G.J. Lewis's name.

\section{Representative specimens}

NORTHERN CAPE.-3220 (Sutherland): Roggeveld Escarpment, entrance to Noudrif Farm, NW of Sutherland, (-AB), 23 Sept. 1981, Goldblatt 6344 (MO); Farm Voëlfontein, banks of Bo-Visrivier, (AB), 11 Oct. 2004, Goldblatt \& Porter 12665 (MO); Farm Koorlandskloof 70, N of Kruiskloof, (-AB), 26 Sept. 2009, Helme 6202 (NBG); Farm Hottentotskloof, SW of Sutherland, (-AC), 2 Oct. 1999, Goldblatt \& Nänni 11193 (MO; PRE); top of Verlatekloof, ,Farm Jakkalsvlei, (-AC), Oct. 1920, Marloth 9646 (PRE); Klein Roggeveld, flats along stream at Farm Oranjefontein, (-DC), 30 Sept. 2004, Goldblatt \& Porter 12660 (MO)

WESTERN CAPE.-3220 (Sutherland): Klein Roggeveld, Kruispad, at turnoff from Matjiesfontein-Sutherland road, (-DC), 19 Sept. 2003, Goldblatt \& Porter 12311 (MO). 3320 (Montagu): Memorial, flats W of the cemetery, (-AB), 9 Sept. 2006, Goldblatt \& Porter 12811 (MO).

4. Ixia brevituba G.J.Lewis in Journal of South African Botany 28: 170 (1962); De Vos: 70 (1999), in part. Type: South Africa, [Northern Cape], 'Quagas [sic] Pass [probably Ganagga Pass], road between Middelpos and Ceres', Sept. 1929, Grant \& Theiler 4931 (BOL, holo!).

I. amethystina J.C.Manning \& Goldblatt: 139 (2006), syn. nov. Type: Northern Cape, 3220 (Sutherland): west of Farm Agterkop, near top of Gannaga Pass, 16 Sept. 1997, Goldblatt \& Manning 10745A (NBG, holo.!, MO!, iso.).

Plants 150-300 mm high, stem either unbranched and then with scale-like leaves at aerial nodes, or with up to 2 short branches, erect below, inclined above, sheathed below by submembranous, red-brown cataphylls. Corm 12-20 mm diam., tunics of medium-textured, wiry, reticulate fibres, extending upward in papery collar 30-70 mm long. Leaves 3 or 4, basal, uppermost completely sheathing lower $2 / 3$ of stem, blades suberect or lowermost slightly falcate, $1.5-2.0 \mathrm{~mm}$ wide, reaching to near top of stem, firm-textured, margins and midrib hyaline, lightly thickened. Spike inclined, nodding in bud, crowded, 5-7-flowered, branches fewer-flowered; bracts dry-membranous, translucent or flushed purple above, outer 5-7 mm long, acute or obscurely 3-dentate, inner \pm as long as outer or slightly shorter, 2-veined

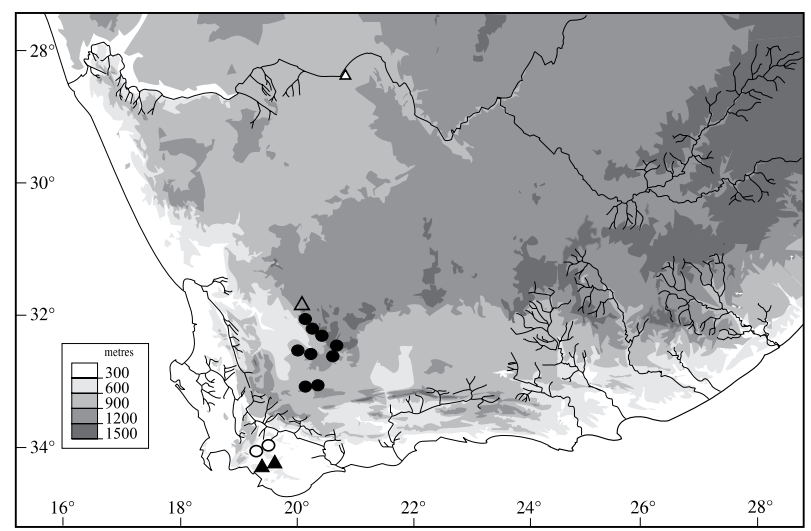

FIGURE 3.-Distribution of Ixia bifolia, $\mathbf{\Delta} ;$ I. brevituba, $\Delta ;$ I. trifolia, $\bullet$; and I. trinervata, $\mathrm{O}$. 

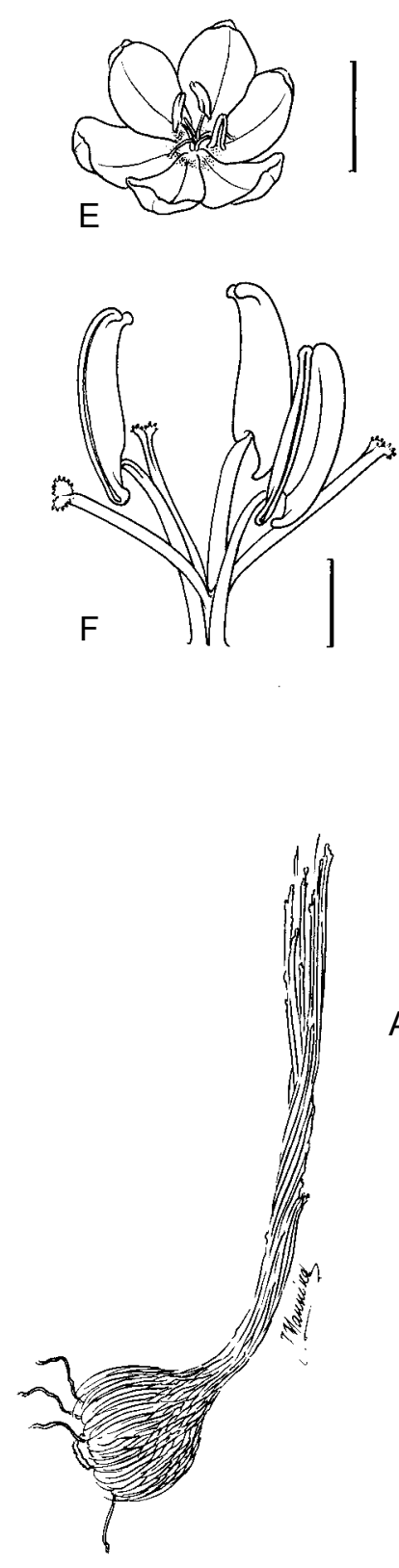

and 2-toothed, margins connate in lower $1.5 \mathrm{~mm}$ around ovary. Flowers rotate, light purple with small dark purple stain in centre, lightly scented; perianth tube \pm funnel-shaped, $\pm 2.3 \mathrm{~mm}$ long, filiform below and clasping style, flaring in distal $1 \mathrm{~mm}$; tepals spreading and slightly concave distally, obovate, \pm narrowed below into a short claw, 12-13 × 7-8 mm. Stamens symmetrically arranged, erect, filaments inserted at apex of tube, diverging above, $2.5 \mathrm{~mm}$ long, blackish purple, anthers \pm oblong, 4.5-5.0 mm long, blackish purple, dehiscing laterally by narrow slits along entire length. Style dividing at or slightly above base of filaments, $\pm 2 \mathrm{~mm}$ long,
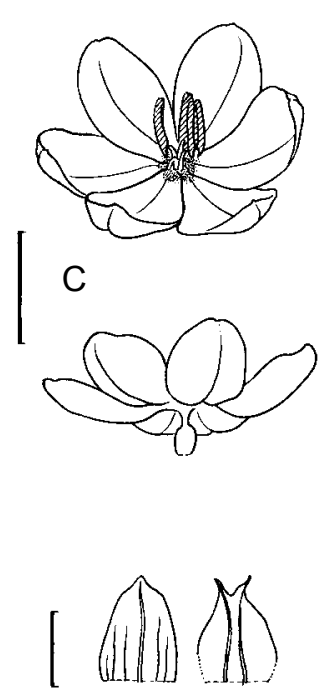

B

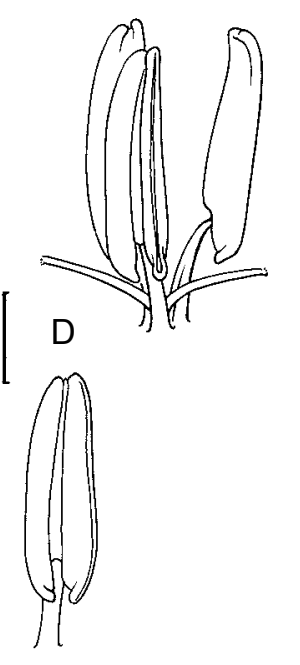

FIGURE 4.-Ixia brevituba, NBG192794 (NBG). A, flowering plant; B, outer (left) and inner (right) bract; C, flower; $\mathrm{D}$, stamens and style branches. I. trifolia, Helme $1662(\mathrm{NBG})$ : $\mathrm{E}$, flower; $\mathrm{F}$, stamens and style branches. Scale bars: A, C, E, $10 \mathrm{~mm}$; B, $5 \mathrm{~mm}$; D, F, $2 \mathrm{~mm}$. Artist: John Manning. branches filiform, involute, stigmatic at apex, purple, falcate, $2.0-2.5 \mathrm{~mm}$ long. Flowering time: late Sept. to early Oct. Figure 4A-D.

Distribution and habitat: Ixia brevituba is known from a small area on the edge of the Roggeveld Escarpment near Ganagga Pass southwest of Middelpos (Figure 3). The few known collections were made within a few kilometres of each other on Farms Zoekop and Agterkop (the type is not localized exactly but is very likely from the same area). Plants grow in stony, light clay in renosterveld. The flowers open widely around 
08:00, even in cool, overcast conditions and remain fully open until late afternoon. Flowers of the closely related I. trifolia, like many other species of sect. Dichone, will not open fully or at all under cool conditions. The only pollinators recorded are small hopliine beetles, Kabousia axillaris. The form of the flowers is consistent with this pollination system. In view of its narrow range we concur with Raimondo et al.'s (2009) conservation status of vulnerable (VU), but we note that the entire range of I. brevituba falls within the Tanqua National Park and future disturbance seems unlikely.

Diagnosis and relationships: distinguished by its pale purple flowers with small, dark eye, Ixia brevituba has relatively broad, blackish anthers that dehisce laterally so that the light-coloured pollen forms a contrasting pale margin to each anther, and short style branches that are \pm as long as the filaments, thus scarcely projecting from between the filaments. The lovely amethyst-coloured flowers are borne on inclined spikes so that they face directly upward in an elegant, arching spray. I. brevituba falls among a small group of species that are endemic or near-endemic to the Roggeveld Escarpment and Klein Roggeveld, including I. curvata, I. rigida, and I. trifolia, all of which share relatively unspecialized, longitudinally dehiscent anthers 3-5 $\mathrm{mm}$ long. Among these species I. brevituba appears to be most closely allied to I. trifolia on the basis of their unusual, inclined spikes, and lateral branches that are decurved and nodding when young. All other species have spikes that are erect from bud to fruit, a feature not explicitly mentioned by Lewis (1962) in the protologue but noted and illustrated by De Vos (1999). The two species also share a perianth tube 2-3 mm long. I. brevituba differs from I. trifolia in its blackish purple anthers and purple perianth tube, which gives the flowers a small, dark central eye, consistently narrower leaves 1.5-2.0 mm wide, and medium-textured corm tunics drawn into a well-developed neck. I. trifolia, like all other species in sect. Dichone, has yellow anthers, although the filaments may be pale mauve, and a pale perianth tube, giving the flowers a well-defined whitish central eye. The leaves of I. trifolia are broader than in I. brevituba, (2.5-)5.0-12.0 $\mathrm{mm}$ wide, and the tunics are more coarsely fibrous, with the lower fibres developed into woody claws but not drawn into a neck above. In addition, the style branches of I. trifolia are longer than the filaments, 4-5 mm long, and project conspicuously between them.

The ranges of Ixia brevituba and I. trifolia complement one another - only a short distance separates the two species and we infer that they share a common ancestor. The differences in their flowers appear to be related to their pollination biology. I. brevituba has flowers that conform to the hopliine beetle pollination syndrome (Goldblatt et al. 1998) and the beetle Kabousia axillaris has been captured while visiting the flowers. All individuals of this insect carried pure loads of Ixiatype pollen on their dorsal thorax and frons (Manning \& Goldblatt 2006). In contrast, Ixia trifolia is pollinated by solitary female anthophorine bees (Goldblatt \& Manning 2007) and possibly also by hopliine beetles.

When described by Lewis (1962), Ixia brevifolia included a collection of a second species, now I. rigida, and the protologue is a composite of the two species.
De Vos (1999) likewise misunderstood I. brevituba and later collections that she associated with the name are also I. rigida. Following De Vos's (1999) interpretation of I. brevituba, Manning \& Goldblatt (2006) described I. amethystina for plants that we now realize conform exactly to the type of I. brevituba. That name now falls into synonymy.

\section{Representative specimens}

NORTHERN CAPE.-3220 (Sutherland): Farm Zoekop, $3 \mathrm{~km} \mathrm{~S}$ of entrance along road to Gannaga Pass, (-AA), 26 Sept. 2002, NBG 192794 (NBG); Farm Zoekop, past ruins near edge of escarpment, (-AA), 24 Sept. 2002, Rösch 154 (NBG); W of farm Agterkop, near the top of Gannaga Pass, 16 Sept. 1997, Goldblatt \& Manning 10745A (MO, NBG).

5. Ixia curvata G.J.Lewis in Journal of South African Botany 28: 171 (1962); De Vos: 70 (1999). Type: South Africa, [Northern Cape], Agterhantamsberg, Moordenaarspoort, 26 miles [ $\pm 39 \mathrm{~km}$ ] NE of Calvinia, 25 Sept. 1952, Lewis 3532 (SAM, holo.!; BOL [SAM 61919]!, PRE!, iso.).

Plants $120-350 \mathrm{~mm}$ high, stem simple or with 1 or 2 upright branches, sheathed at base by long, chestnutbrown cataphylls and a collar of fibres. Corm 12-20 mm diam., tunics of medium-textured fibres. Leaves usually 4 or 5 , lower 3 or 4 with sword-shaped to falcate blades, $\pm 1 / 2$ as long as stem and (2-)3-5 mm wide, uppermost leaf entirely sheathing, main veins and margins slightly to moderately thickened. Spike flexuose, erect, 2-ranked, mostly 6-12-flowered; bracts membranous, translucent, 4-5 mm long, outer with prominent central vein or secondary veins equally prominent, 3-lobed with central lobe largest or \pm equally 3-lobed, inner slightly shorter than outer, 2-veined and 2-toothed. Flowers nodding with tepals held vertically, deep pink (sometimes called purple), white (sometimes edged with dark pink) at base of tepals, unscented; perianth tube filiform but expanded near mouth, 3-5 mm long; tepals spreading, oblong, (8-)10-14 × 4-8 mm. Stamens symmetrical in bud, becoming unilateral in open flower, straight, held horizontally at right angles to tepals; filaments inserted at mouth of tube, filiform, 2-3(-4) mm long, white; anthers oblong-linear, 2.5-4.0 mm long, yellow, dehiscing completely by longitudinal slits. Style dividing between base and lower $1 / 3$ of filaments, style $\pm 2 \mathrm{~mm}$ long, branches tubular, strongly falcate, stigmatic apically, white. Flowering time: mid-Aug. to late Sept. Figure 5.

Distribution and habitat: Ixia curvata has a relatively modest range for sect. Dichone, extending in the western Karoo from the eastern end of the Hantamsberg at Moordenaarspoort northeast of Calvinia southward to Middelpos on the Roggeveld Plateau (Figure 1). The range remains poorly documented and there are no collections from Middelpos itself although we have seen the species on the commonage there. Our description is based largely on the Middelpos population and the illustration here is from this population. Plants favour the red clay soils derived from dolerite but are also found in pale clay ground derived from Karoo shales. Pollination of I. curvata has not been studied. Raimondo et al. (2009) regarded the conservation status as of Least Concern (LC) and we concur, noting the relatively modest range of the species. 


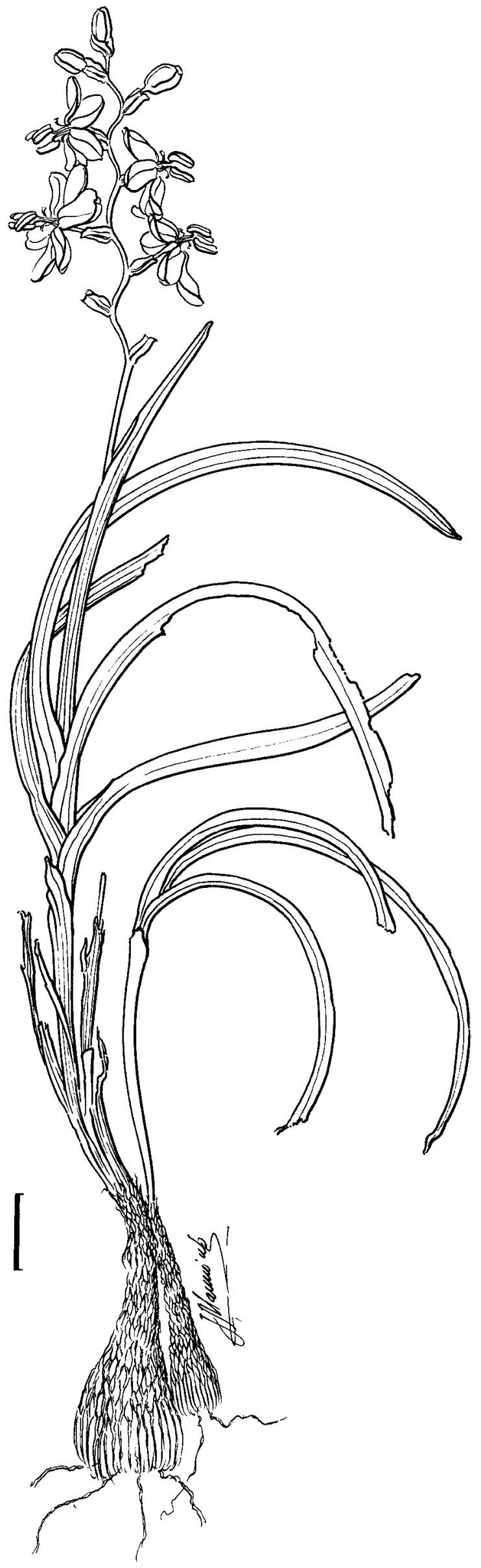

FIGURE 5.-Ixia curvata, Middelpos, without voucher. Scale bar: 10 mm. Artist: John Manning.
Diagnosis and relationships: relatively low growing, Ixia curvata is a small plant, seldom exceeding 200 $\mathrm{mm}$ in height (although taller plants are known) and has nodding, pink flowers with tepals held vertically with stamens borne horizontally. Like other members of ser. Euanthera, the anthers split completely. The four or five leaves are typically falcate and leathery rather than fibrotic. Its immediate relationships remain uncertain. Other species of the series have upright flowers with tepals spreading horizontally. The plants are notable in the thick collar of fibres around the base and chestnutbrown cataphylls.

The species was first collected by Rudolf Marloth in October 1920, but the label data localizing the plants from 'plains near Tulbagh' is an obvious mistake. Marloth collected in the Roggeveld and nearby in October 1920 when he also made the first collections of Ixia rigida (initially assigned to I. brevituba) and I. trifolia, thereby establishing the presence of sect. Dichone in the Western Karoo.

\section{Representative specimens}

NORTHERN CAPE. 3119 (Calvinia): lower clay slopes of the Hantamsberg N of Downes Siding, (-BD), 12 Sept. 2004, Goldblatt \& Porter $12411(\mathrm{MO}) ; 4.5$ miles $[ \pm 6.8 \mathrm{~km}] \mathrm{SSE}$ of Calvinia, (-DB), 21 Sept. 1955, Acocks 18504 (PRE). 3120 (Williston): $35 \mathrm{~km} \mathrm{SE}$ of Calvinia to Middelpos on Blomfontein road, (-CA), 30 Sept. 1976, Goldblatt 4281 (MO). Uncertain localities: 'Plains near Tulbagh,' Oct. 1920, Marloth 9936 (PRE); Van Rhyns Pass, 15 Sept. 1953, Taylor 3967 (NBG).

6. Ixia trinervata (Baker) G.J.Lewis in Journal of South African Botany 28: 169. (1962); De Vos: 75 (1999). Tritonia trinervata Baker: 191 (1892); Baker: 212 (1896). Type: South Africa, [Western Cape], Appelskraal, Riviersonderend, Ecklon \& Zeyher Irid. 242 (K, holo.!, G, Z, iso.).

Plants $250-450 \mathrm{~mm}$ high, stem usually unbranched or with a single short branch, with membranous cataphylls enclosing base. Corm 9-18 mm diam., tunics of firm, medium-textured, netted fibres. Leaves 2, lower 1 \pm basal, upper 1 sheathing stem in lower $1 / 2$, blades lanceolate, 4-10 mm wide, conspicuously 3-veined, main vein moderately thickened, secondary veins slightly less so, margins not or barely thickened. Spike flexuose, mostly 7-122-flowered; bracts membranous, translucent, sometimes turning rusty brown in upper $1 / 3$, outer 5-6 mm long, with prominent central vein and up to six secondary veins, 1-toothed or \pm fringed, inner \pm as long as outer, 2-veined and 2-toothed. Flowers rotate, deep rose pink, unscented; perianth tube filiform, 4-5 $\mathrm{mm}$ long, clasping style; tepals spreading, ovate-elliptic, obtuse to retuse, $12-15 \times 6-8 \mathrm{~mm}$. Stamens symmetrically arranged, erect; filaments inserted at mouth of tube, filiform, 2-4 mm long, \pm white; anthers erect, suborbicular, $\pm 2 \mathrm{~mm}$ long, yellow, thecae acute and recurved at base, dehiscing by narrow, longitudinal slits almost to apex. Style dividing at base of filaments, branches falcate, 2.5-3.0 mm long, tubular-filiform, stigmatic apically, pale pink.

Distribution and habitat: a narrow endemic of the Caledon District, Ixia trinervata extends from Elgin Station and the Farm Arieskraal in the west to Riviersonderend in the east, a linear distance of some $65 \mathrm{~km}$ (Fig- 
ure 3). Plants favour clay soils and grow in renosterveld, often in stony ground. There is evidence that flowering is stimulated after fire and we have seen plants blooming well on the Farm Vleitjies after a summer burn. We agree with Raimondo et al.'s (2009) estimate of near threatened status (NT) for I. trinervata.

Diagnosis and relationships: first described by J.G. Baker (1892) as Tritonia trinervata and transferred to Ixia by G.J. Lewis (1962), I. trinervata is readily recognized by the presence of just one foliage leaf, the blade narrowly sword-shaped and with three \pm equally conspicuous veins and unthickened margins. A second leaf is largely to entirely sheathing, although relatively broad. The flowers are an intense, bright mauve pink or red-magenta. Lewis (1962) considered the species most closely related to usually pale pink-flowered I. stricta, which blooms later in the season, at which time its 3-5 leaves are usually dry. Both species favour clay or clay loam soils. The new I. bifolia, described here, recalls $I$. trinervata in its single foliage leaf, but the leaf blade is much narrower than in I. trinervata, with a single main vein embedded in the leathery-succulent leaf tissue. When dry the leaf margins appear particularly thickened, unlike those of I. trinervata. The flowers of I. bifolia are slightly smaller than those of I. trinervata and have unusual, almost straight, deep pink style branches in marked contrast to the pale pink, falcate style branches of I. trinervata.

\section{Representative specimens}

WESTERN CAPE.-3419 (Caledon): Diepklowe Nature Reserve, $14 \mathrm{~km} \mathrm{~N}$ of Botrivier, Farm Welgemoed, (-AA), 3 Sept. 2001, Helme 2152 (NBG); Elgin, Die Hawe, near Post Office, clay ground, (-AA) 11 Oct. 2000, Goldblatt 11639 (MO); Lebanon Forest Reserve, Houw Hoek, (-AA), 26 Sept. 1954, Martin 1043 (NBG), Lewis 4178 (PRE, SAM); slopes of Eseljag Pass, near Farm Vleitjies, clay soil in renosterveld, (-AB), 30 Sept. 2000, Goldblatt \& Nänni 11597 (MO, PRE); 18 Sept. 2011, Goldblatt \& Manning 13642 (MO, NBG).

\section{Ixia bifolia Goldblatt \& J.C.Manning, sp. nov.}

TYPE.-Western Cape, 3419 (Caledon): northern slopes below Shaw's Pass, Farm Treintjiesrivier, (-AD), 13 Sept. 2009, Goldblatt \& Manning 13444 (NBG, holo.; MO, PRE, iso.).

Plants mostly 160-300 mm high, stem unbranched, with short scale $\pm 1 \mathrm{~mm}$ long, inserted $12-30 \mathrm{~mm}$ below base of spike, sheathed basally by dry, brown cataphylls. Corm 10-12 mm diam., tunics of fine, soft to firm fibres extending upward as collar, bearing cormlets at base. Leaves 2, lower 1with long sheath, \pm lanceolate, blade $60-80 \times(3-) 5-8 \mathrm{~mm}$, reaching up to middle of stem, leathery-succulent, main vein not raised when alive (visible as a pale line when held to light), slightly raised when dry, margins thickened, hyaline, transparent when alive, when dry raised above mesophyll and yellow, upper leaf largely sheathing, sometimes with short free blade similar to basal but 2-3 mm wide. Spike mostly 4-7-flowered, \pm straight; bracts translucent pink with purple veins, 5-6 mm long, outer with 3 main veins terminating in acute teeth and 1 or 2 secondary veins along margins, inner 2-veined and acutely 2-toothed. Flowers rotate, upright, deep pink, darker toward tepal bases, rose-scented; perianth tube filiform, 5-6 $\mathrm{mm}$ long; tepals obovate, $12-14 \times 5-7 \mathrm{~mm}$. Stamens symmetri- cally arranged; filaments filiform, inserted at mouth of narrow part of tube, $\pm 1.5 \mathrm{~mm}$ long, deep pink (drying purple); anthers suborbicular, 2.0-2.5 mm long, yellow, thecae obtuse basally, dehiscing completely or almost so by narrow slits. Style dividing at base of filaments, style branches 3.8-4.0 $\mathrm{mm}$ long, deep pink (drying purple), \pm straight, extending outward below anthers, expanded and bilobed at tips. Capsules globose, $\pm 4 \mathrm{~mm}$ diam. Flowering time: mostly late Aug. to mid-Nov. but Dec. and early Jan. in the Caledon Swartberg. Figure 6.

Distribution and habitat: restricted to the Caledon District, Ixia bifolia is known from the northern slopes of Shaw's Mtn south of Caledon and from the lower slopes of the Swartberg east of Caledon (Figure 3). The soil at the Shaw's Mtn site is hard, stony clay and the habitat there is shared by the rare Tritoniopsis flexuosa (L.f.) G.J.Lewis (known from just two other localities). With its narrow range and just two known populations, one small and near a major road, we suggest a conservation status of (VU), Vulnerable.

Diagnosis and relationships: Ixia bifolia seems at first to belong in the I. micrandra-confusa complex, which also has very slender stems and small flowers but it stands out in the very short, leathery-succulent foliage leaf blade, up to $80 \mathrm{~mm}$ long and 5-7 $\mathrm{mm}$ wide. The leaf has a single, prominent vein and moderately thickened margins. The flowers seem most like those of I. confusa but the short, deep pink filaments $\pm 1.5 \mathrm{~mm}$ long and similarly deep pink, straight style branches \pm $4 \mathrm{~mm}$ long (both drying purple) are quite different from I. confusa, which has white filaments $1.3-2.5 \mathrm{~mm}$ long and white, strongly falcate style branches $1-2 \mathrm{~mm}$ long. We suspect that I. bifolia may be more closely allied to I. trinervata, which has slightly larger flowers on longer spikes but also a single foliage leaf, this relatively broad and always with three prominent veins and margins not thickened. I. bifolia shares with other members of the $I$. micrandra complex the finely fibrous corm tunics that extend upward around the stem base. Stems are almost always unbranched and have an odd feature, a small, nearly microscopic, translucent scale and prophyll, \pm $1 \mathrm{~mm}$ long, inserted $12-30 \mathrm{~mm}$ below the base of the spike. Stems of I. confusa may be branched and are normally taller than in I. bifolia but also have a translucent stem scale in populations from the Swartberg and sometimes elsewhere across its range. I. confusa has 3 or 4 linear leaves, usually $\pm 2 \mathrm{~mm}$, but occasionally to $4 \mathrm{~mm}$ wide.

\section{Representative specimens}

WESTERN CAPE.-3419 (Caledon): N slopes below Shaw's Pass E of main road, (-AD), 16 Sept. 2009, Goldblatt \& Manning 13640 (MO, NBG, K); lower slopes of Caledon Swartberg, grazed field E of Drayton Siding, (-BA), 16 Sept. 2011, Goldblatt \& Manning 13641 (MO, NBG).

8. Ixia confusa (G.J.Lewis) Goldblatt \& J.C.Manning, stat. nov. I. micrandra var. confusa G.J.Lewis: 162 (1962); De Vos: 73 (1999). Type: South Africa, [Western Cape], Montagu, Donkerkloof, 26 Sept. 1946, Compton 18481 (NBG, holo.!; BOL!, iso.).

Plants (150-)250-500 $\mathrm{mm}$ high, stem simple or 1-branched, with short scale $\pm 1 \mathrm{~mm}$ long, inserted 


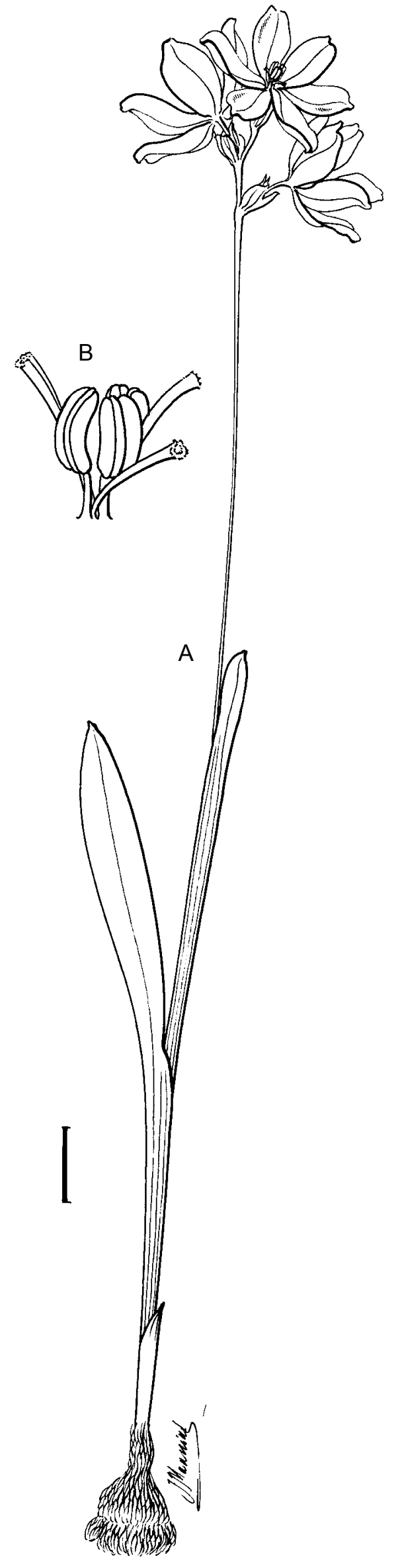

FIGURE 6. - Ixia bifolia, Goldblatt \& Manning 13444 (NBG). A, flowering plant; B, stamens and style branches. Scale bar: $10 \mathrm{~mm}$. Artist: John Manning.
25-40 mm below base of spike, sheathed basally by green, leathery to firm, dry cataphylls. Corm 8-10 mm diam., tunics of fine, soft fibres sometimes extending upward in a weakly developed collar. Leaves (2)3(4), lower (1)2 or 3 with linear to narrowly sword-shaped blades, $\pm 1 / 3$ as long to reaching top of stem, 1.5-4.0 $\mathrm{mm}$ wide, upper leaf largely sheathing, with short free blade. Spike slightly flexuose, (2-)5-9(-12)-flowered; bracts membranous, becoming dry from tips, $4-5 \mathrm{~mm}$ long, outer 1 - or 3-veined, irregularly $2-3(-5)$-lobed or shortly toothed, inner often slightly longer than outer, 2-veined and 2-toothed. Flowers rotate, upright, pink to light red-purple, rose-scented; perianth tube filiform, 3-4 mm long; tepals spreading, \pm ovate, mostly $12-15$ $\times$ 6-7 mm. Stamens symmetrically arranged, erect; filaments inserted at mouth of tube, filiform, $1.0-2.8 \mathrm{~mm}$ long; anthers oblong, 2.0-2.3 mm long, yellow, thecae acute and recurved at base, usually dehiscing longitudinally from base almost to apex. Style dividing at or up to middle of filaments, style branches $1.5-2.0 \mathrm{~mm}$ long, falcate, tubular with expanded ciliate, stigmatic tips, sometimes shortly forked apically. Flowering time: mostly Jul.--early Dec.

Distribution and habitat: Ixia confusa occurs in the mountains of southern Western Cape, from near Elim and the Riviersonderend Mtns in the west through the Langeberg to the Paardevlei Mtns near Farm Bonnievale at the western end of the Outeniqua Mtns (Vlok 709 NBG, PRE), and inland in the Great Swartberg (Figure 7) where it has been recorded from Swartberg Pass, Meiringspoort, and Blesberg slightly further east. An outlying collection (Marloth 2429 PRE) from Montagu Pass near George extends the range slightly south. We have encountered plants (Goldblatt \& Manning 12946) on moist southwest-facing slopes in loamy clay in renosterveld-thicket transition vegetation. The flowers of our collection were strongly rose-scented. We suspect that plants flower particularly well after fire but our collection was made in veld that had not burned for over 10 years. Occurring mostly in montane habitats, there seems no current threat to the species and we agree with Raimondo et al.'s (2009) (LT, as I. micrandra var. confusa), Least Threat conservation status.

Diagnosis and relationships: known to G.J. Lewis (1962) as Ixia micrandra var. confusa, we raise the taxon to species rank after examining living plants and

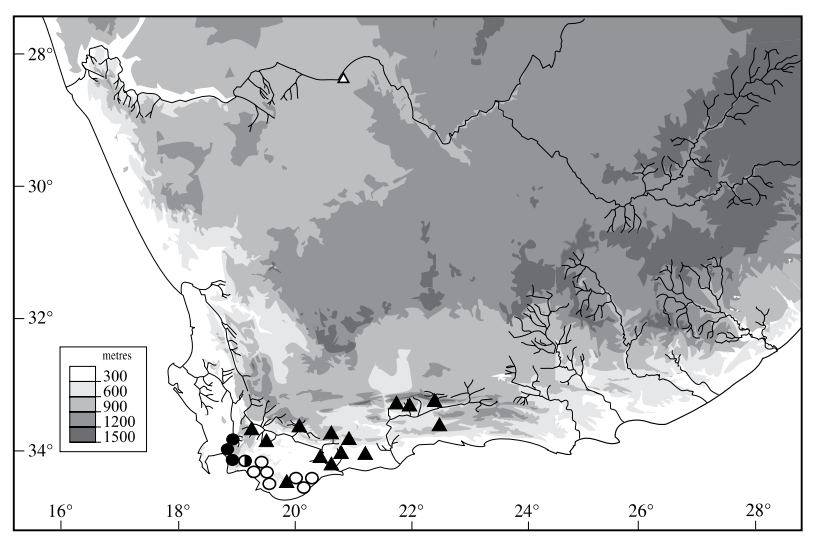

FIGURE 7.-Distribution of Ixia confusa, $\mathbf{\Delta}$; I. micrandra, $\circ$; and I. minor, $\bullet$. 
comparing them with I. micrandra. Both I. micrandra and closely related $I$. minor $(=I$. micrandra var. minor G.J.Lewis) have corms with finely fibrous tunics that extend upward in a collar around the base of the stem, terete to subterete or linear leaves mostly $1.0-1.5 \mathrm{~mm}$ at widest, and spikes of up to 6 flowers. I. confusa has corms with similar finely fibrous tunics, sometimes without a collar of fibres around the base, but plane leaves $1.5-4.0 \mathrm{~mm}$ wide, and spikes with as many as 12 flowers. I. micrandra has anthers 3-4 $\mathrm{mm}$ long, and slender, \pm straight, ascending style branches 3-4 $\mathrm{mm}$ long, thus quite different from the shorter anthers, $\pm 1.0-2.5 \mathrm{~mm}$ long, and falcate style branches $1.5-2.5$ $\mathrm{mm}$ long of $I$. confusa. The style branches of I. confusa match those of I. minor but the terete or subterete leaf blades, flattened filaments and consistently few-flowered spikes of the latter immediately separate them.

Ixia confusa may also be confused with the new $I$. bifolia but this species has a single, relatively broad, leathery-succulent foliage leaf and flowers with shorter filaments $\pm 1 \mathrm{~mm}$ and longer, straight style branches \pm $4 \mathrm{~mm}$ long. Both the filaments and style branches of $I$. bifolia are dark pink and dry dark purple, unlike the pale filaments and style branches of I. confusa, which dry to a pale, almost colourless state.

Annotations by G.J. Lewis on collections of Ixia confusa from the Swartberg indicate that at one time she considered these populations a separate species, which she intended to call I. aestivalis, in part because of their late flowering, from late October to early December. We find that collections from the Swartberg also differ in having slightly shorter filaments, 1-2 mm long, than typical $I$. confusa (1.5-2.8 $\mathrm{mm}$ long), the style sometimes dividing above the mouth of the perianth tube (opposite the middle of the filaments in Goldblatt 7962), and anther dehiscence sometimes not reaching the middle of the thecae. The plants have a small, translucent scale and prophyll on the upper part of the stem, a feature occasionally present in southern populations of $I$. confusa. Additional study may show that the later-flowering Swartberg populations merit separate taxonomic status but we find no consistent character differences between them.

\section{Representative specimens}

\section{[* = apparently no collar around base of stem]}

WESTERN CAPE.-3319 (Worcester): eastern foot of Stettynsberg, (-CD), 31 July 1949, Esterhuysen 15590 (BOL, NBG, PRE); slopes of Boesmanskloof Pass, MacGregor, (-DC), 13 Sept. 1962, Lewis 6067* (NBG, PRE); top of Boesmanskloof Pass, MacGregor, (-DC), 13 Sept. 1962, Lewis 6080 (NBG). 3320 (Montagu): foot of Tradouw Pass, (-DC), 18 Sept. 1968, Marsh 875 (PRE). 3321 (Ladismith): Paardevlei Mtns N of Farm Bonniedale, $1500 \mathrm{ft}$ [ $\pm 460 \mathrm{~m}]$ (-DD), 24 Sept. 1983, Vlok 709* (NBG, PRE). 3322 (Oudtshoorn): summit, Swartberg Pass, (-AC), Dec. 1906, H. Bolus 12336 (BOL); Swartberg Pass, (-AC), 5 Nov. 1958, Werdermann \& Oberdieck 843 (B, PRE), 22 Oct. 1986, Goldblatt 7962 (MO, PRE); Swartberg, sandy flats SW of Blesberg, (-BC), 7 Jan. 1975, Thompson 2274 (PRE); Meiringspoort, S slopes, (-BC), 16 Oct. 1955, Esterhuysen 24880 (BOL, MO, PRE); Montagu Pass, George, (-CD), Marloth 2429 (PRE). 3419 (Caledon): Uintjieskuil near Elim, (-DB), Sept. 1926 Smith 3182* (PRE). 3420 (Bredasdorp): S of Swellendam on road to Bontebok Park, light stony clay, (-AB), 26 Aug. 2000, Goldblatt 11430 (MO); coastal renosterveld hills at Goerreesoe, S slope, (-AD), 30 Aug. 1962, Acocks 22672 (PRE); clay loam slopes between Heidelberg and Strawberry Hill, in renosterveld, (-BB), 4 Sept. 2007, Gold- blatt \& Manning 12946 (MO, NBG, PRE). 3421 (Riversdale): near Oudebosch crossing, Korente River crossing, Riversdale, (-AA), 16 Sept. 1981, Hugo 2773 (PRE).

9. Ixia micrandra Baker in Journal of Botany 1876: 237 (1876); Baker: 78 (1896); Lewis: 159 (1962); De Vos: 71 (1999). Type: South Africa, [Western Cape], Houw Hoek Mtns, July 1830, Zeyher 4011 (K, lecto.! designated by Lewis: 161 (1962); PRE!, SAM!, S, Z, isolecto.).

Plants 250-350 $\mathrm{mm}$ high, stem unbranched, base sheathed by membranous to \pm dry, brown cataphylls. Corm 9-18 mm diam., tunics of fine fibres extending upward as a collar. Leaves 2, lower $1 \pm$ basal, upper 1 sheathing the stem in lower $1 / 2$ to $2 / 3$, free distally for up to $100 \mathrm{~mm}$, blades linear, $(0.5-) 1.0-1.5(-2.0) \mathrm{mm}$ wide, margins and midrib lightly thickened, hyaline when dry. Spike erect, \pm straight, (1-)2-4(-6)-flowered; bracts membranous, translucent, sometimes suffused with purple distally, outer 5-7 $\mathrm{mm}$ long, prominently 3 -veined and usually with secondary veins evident, acutely 3-cuspidate, sometimes central cusp smaller, inner \pm as long as outer or slightly longer, 2-veined and 2-cuspidate. Flowers rotate, pale mauve-pink; perianth tube filiform, 3-4 mm long, clasping style; tepals spreading, ovate-elliptic, 12-15 × 4-6 mm. Stamens symmetrically arranged, erect; filaments inserted at mouth of tube, linear, straight, 0.6-1.8(-2.5) mm long, \pm pale pink; anthers oblong, 2.0-2.6 mm long, erect, yellow, thecae slightly recurved basally and acute, dehiscing completely from base by longitudinal slits. Style dividing at or shortly above base of filaments, branches \pm straight and diverging to slightly arched, $2-5 \mathrm{~mm}$ long, usually longer than stamens, filiform-involute, stigmatic and sometimes forked at apex, pale pink. Flowering time: mostly late Jul.--early Sept., occasionally later.

Distribution and habitat: extending from Houw Hoek, Bot River and the Caledon Swartberg to Bredasdorp and De Hoop (Figure 7), Ixia micrandra typically occurs on sandstone slopes and flowers well only in seasons immediately after veld fires. A collection from De Hoop is from pockets of sandy soil in limestone pavement, an unusual habitat for the species. Largely montane, we see no current threat to the species and endorse Raimondo et al.'s (2009) (LT), least threat, status.

Diagnosis and relationships: treated by G.J. Lewis (1962) as including the two additional varieties, var. confusa and var. minor, we have no doubt that I. micrandra is allied to these two taxa, which are here raised to species rank. I. micrandra stands out in the group in its long, narrow, almost linear filaments and its style branches, which are unusually long at $2.0-3.5 \mathrm{~mm}$, and straight or slightly arched, thus extending between the bases of the anthers. I. confusa has similarly slender but somewhat shorter filaments, slightly shorter anthers, and shorter, strongly arched style branches, 1.5-2.0 $\mathrm{mm}$ long. The leaves of $I$. confusa have plane, usually wider blades up to $4 \mathrm{~mm}$ wide (vs. $0.5-1.5(-2.0 \mathrm{~mm}$ ) and without the prominently thickened main vein of $M$. micrandra. The style branches are also strongly arched in I. minor but that species has unusual flattened, lan- 
ceolate filaments, narrowed and kinked at the tips. The ranges of $I$. micrandra and $I$. minor are almost complementary, that of $I$. micrandra extending east of $I$. minor, but the two have been collected growing and flowering on the same day in the Houw Hoek Mtns, where their distributions overlap.

The only significant variant of Ixia micrandra we have seen is from near Bot River (MacOwan in Herb. Norm. Austr. Afr. 262). Plants of this population have unusual thick, fleshy leaf blades, but the flowers and other features accord with the species.

\section{Representative specimens}

WESTERN CAPE. 3419 (Caledon): Houw Hoek, (-AA), 17 Sept 1987, [collected with I. minor, Beyers 17, on same day], Beyers 22 (NBG); Bot River, Langhoogte, (-AA), Aug., Ecklon \& Zeyher Irid. 92 (MO); Caledon Baths, (-AB), July 1892, F. Guthrie 2531 (BOL); Caledon Swartberg and vicinity of the baths, $(-\mathrm{AB}, \mathrm{BA})$, August 1830, Zeyher 4009 (PRE); Highlands, low slopes between Kleinmond and Bot River (-AC), 27 July 1960, Lewis 5733 (NBG); raised plain between the mountains and mouth of the Bot River, (-AC), July 1885 , MacOwan in Herb. Norm. Austr. Afr. 262 (BOL, PRE); Kleinmond commonage, (-AC), 15 Aug. 1982, Burman 852 (BOL); Hermanus, behind Golf Course, deep sand, $60 \mathrm{~m},(-\mathrm{AD}), 1$ Aug. 1984, S. Williams 1042 (MO); Caledon Swartberg, well drained sandy soil, (-BA), 1 Aug. 2004, Raimondo CR278 (NBG); Genadendal, mountains at \pm $4500 \mathrm{ft}$ [1 $400 \mathrm{~m}$ ], (-BA), 27 Oct. 1899, Galpin 4686 (BOL), Salmonsdam Reserve, Stanford, burnt slopes, $1000 \mathrm{ft}$, (-BB), 31 Aug. Goldblatt 421 (BOL); 2 miles [3 km] NW of Papiesvlei P.O., (-BC), 25 July 1962, Acocks 22449 (PRE); Bredasdorp, hillside, (-BD), 27 July 1955, Van Niekerk 430 (BOL). 3420 (Bredasdorp): De Hoop, Potberg Nature Reserve, upper slope above Boskloof, back sandy ground, (-BC), 6 Sept. 1978, Burgers 1067 (PRE).

10. Ixia minor (G.J.Lewis) Goldblatt \& J.C.Manning, stat. nov. I. micrandra var. minor G.J.Lewis: 162 (1962); De Vos: 73 (1999). Type: South Africa, [Western Cape], Hottentots Holland Mtns, 10 Sept. 1928, J. Hutchinson 481 (BOL, holo.!; K, PRE!, iso.).

Plants 200-300 mm high, stem unbranched, sheathed by membranous to dry, brown cataphylls at base. Corm 8-10 mm diam., tunics of fine fibres extending upward as a collar, often in a dense mass. Leaves 2 , lower $1 \pm$ basal, upper 1 sheathing stem in lower $1 / 2$ to $2 / 3$, free distally for short distance, blades \pm terete or oval in section, up to $1 \mathrm{~mm}$ diam., main vein evident only when dry. Spike erect, straight, mostly 2-4-flowered, bracts membranous, translucent, usually flushed purple, outer 5-7 mm long, usually prominently 3-veined, shallowly 3-lobed to acutely 3-toothed, inner bract \pm as long as or slightly longer than outer, 2-veined and 2-lobed or 2-toothed. Flowers rotate, bright pink to mauve pink; perianth tube filiform, 3-5 $\mathrm{mm}$ long, clasping style; tepals spreading, ovate-elliptic, 12-14 × 5-6 mm. Stamens symmetrically arranged, erect, filaments flattened, \pm lanceolate but narrowed and kinked at tips, inserted at mouth of tube, \pm white, $1.0(-1.5) \mathrm{mm}$ long, anthers ovoid, $\pm 1.0 \mathrm{~mm}$ long, erect, yellow, thecae acute but abruptly incurved and touching at base, dehiscing fully by longitudinal slits, often more widely at base, yellow. Style dividing opposite base to middle of filaments, branches up to $2 \mathrm{~mm}$ long, involute, tubular-falcate, \pm compressed, narrowed at tips, stigmatic apically, white. Flowering time: late Jul.--mid-Sept., rarely later.

Distribution and habitat: a narrow endemic of the southwestern Cape, Ixia minor occurs from Franschhoek
Pass and the Wemmershoek Mtns south though the Hottentots Holland and Kogelberg Mtns to Houw Hoek (Figure 7). The habitat, stony sandstone slopes, is the same as that for I. micrandra and as in that species we see no current threat and suggest a least threat (LT) conservation status.

Diagnosis and relationships: Ixia minor, treated as var. minor of I. micrandra by Lewis (1962) but raised here to species rank, is evidently closely allied to the more widespread I. micrandra, with which it is easily confused unless floral details are examined carefully. Both share a slender, usually unbranched stem, small corms with fine, netted tunics that extend upward in a collar around the base, and a dry, often brown, upper cataphyll. The critical differences between the two species lie in their flowers: I. minor has flattened, \pm wedgeshaped to oblanceolate filaments abruptly narrowed at the tips, shorter and broader anthers, often not dehiscing to the apex and kinked at the base with the bases of the thecae turned inwards and touching, and shorter, wider, strongly arched style branches slightly compressed and narrowed at the tips. To these microscopic details can be added a deep pink perianth. Flowers of I. micrandra have pale pink to purple-pink tepals, linear filaments, longer, oblong anthers dehiscing to the apex and longer, more slender style branches, \pm straight to slightly arched.

The leaves of the two species also differ: those of Ixia minor are subterete to oval in section, thus when alive without margins or evident central vein, whereas $I$. micrandra has plane, linear leaf blades with somewhat thickened margins and, when dry, a raised main vein. Floral differences between I. minor and I. micrandra are illustrated in detail in the accounts by both Lewis (1962) and De Vos (1999). A color photograph of I. minor (Manning et al. 2002: 242) under the name I. micrandra clearly shows the short, recurved style branches of the species. Compelling evidence for their separation is provided by collections of both species made by the late $\mathrm{J}$. Beyers in the Houw Hoek Mtns flowering on the same date and sufficiently different in appearance that Beyers gave them different collection numbers. Habitat differences, if any, were not recorded.

\section{Representative specimens}

WESTERN CAPE.-3319 (Worcester): Wemmershoek, SE end, 3 000-4 000 ft [915-1 220 m], (-CC), 19 Oct. 1943, Esterhuysen 9060 (BOL); Franschoek Pass, \pm 1 km S of summit, (-CC), 9 Oct. 1973, Boucher 2337 (PRE). 3418 (Simonstown): W foot of Sir Lowry's Pass, (-BB), Aug. 1985, De Vos 2585 (NBG); Sir Lowry's Pass mountains, (-BB), Sept. 1894, H. Bolus 7850 (BOL); Steenbras River, 600 m, (BB), 14 Oct. 1894, Schlechter 5402 (PRE). 3419 (Caledon): Elgin, (AA), 19 Sept. 1931, Levyns 3341 (BOL); Hottentots Holland, Moordenaarskop and Sugar Loaf, (-AA), 30 Oct. 1943, Esterhuysen 9123 (BOL); Houw Hoek, (-AA), 17 Sept. 1987 [collected with I. micrandra, Beyers 22, on same day], Beyers 17 (NBG).

\section{Ser. Dichone}

Flowers upright or nodding, radially symmetric (Ixia stricta) or zygomorphic. Stamens symmetrically arranged (Ixia stricta) or unilateral and horizontal to pendent; anthers oblong, recurved and acute at base, dehiscing incompletely from base. Style branches always falcate. 
7 spp., centred in the western half of Western Cape, but with isolated populations in northern Namaqualand and the Bokkeveld Mtns of Northern Cape.

11. Ixia stricta (Eckl. ex Klatt) G.J.Lewis in Journal of South African Botany 28: 167 (1962); De Vos: 73 (1999). Tritonixia stricta Eckl. ex Klatt: 357 (1882). Tritonia scillaris var. stricta (Eckl. ex Klatt) Baker: 191 (1892). Type: Western Cape, Caledon, Swartberg and vicinity of the Baths, December 1830, Zeyher 4008 (SAM, lecto.!, designated by Lewis: 162 (1962); K, PRE!, isolecto.).

\section{Agretta stricta Eckl.: 23 (1827), nom. nud.}

Plants $200-450 \mathrm{~mm}$ high, stem simple or with 1 or 2 \pm erect branches subtended by acute, translucent bracts and prophylls, sheathed at base by short, dry cataphylls. Corm mostly $\pm 10-15 \mathrm{~mm}$ diam., tunics of mediumtextured, shaggy fibres. Leaves (3)4 or 5, often \pm dry at flowering, basal, lower 2 or 3 with blades plane, 4-9 mm wide, upper 1 or 2 sheathing stem in lower $1 / 2$ to $2 / 3$, free distally for short distance, margins and main vein thickened (hyaline when dry). Spike erect, flexuose, 6-12(-18)-flowered, bracts membranous, translucent, outer 5-6 mm long, usually with 1 prominent vein, and 1-toothed, inner bract \pm as long or slightly shorter or longer, 2-veined and 2-toothed. Flowers rotate, pink to purple, pale yellow edged with darker pink at tepal bases, sweetly scented (Viviers 1150), perianth tube filiform, 4-5 mm long, clasping style, tepals spreading, obovate, \pm obtuse, $\pm 10 \times 4-5 \mathrm{~mm}$. Stamens symmetrically arranged, filaments $1.0-1.5 \mathrm{~mm}$ long, white, anthers oblong, $\pm 2 \mathrm{~mm}$ long, erect, yellow, thecae acute and slightly recurved at base, dehiscing near base by longitudinal slits. Style dividing opposite base of filaments, branches arching outward, $\pm 1.5 \mathrm{~mm}$ long, falcate, tubular, stigmatic apically, pale pink. Flowering time: Nov.-mid-Dec.

Distribution and habitat: restricted to the CaledonBredasdorp area of Western Cape, Ixia stricta extends from the Houw Hoek Mtns in the west to Bredasdorp in the southeast (Figure 1). Typically flowering late in the year, in November and December, I. stricta is poorly collected. Not surprisingly the foliage is often more-orless dry at flowering. Plants occur mostly in montane habitats, but usually at fairly low elevations, in sandstone and loamy clay soils. Raimondo et al. (2009) suggest a conservation status of (LC), least concern, but we suggest that (NT), near threatened, is more appropriate.

Diagnosis and relationships: while not particularly distinctive in its radially symmetric flowers with short, erect stamens, Ixia stricta is identified in ser. Dichone by a combination of the rotate flowers and a basal fan of (3) 4 or 5 sword-shaped leaves, the blades with a prominent main vein and thickened margins. The sweetly scented flowers have a filiform tube about half as long as the tepals and a particularly short style $\pm 1 \mathrm{~mm}$ long. Blooming late in the season, in November and December, the leaves are often dry or partly so, a feature unusual in the genus.

History: the plant illustrated by Jacquin (1792) and misidentified as Ixia polystachya L. is the earli- est record of Ixia stricta and this illustration is also one of two sources cited by Ker Gawler (in Sims 1801) for his I. scillaris var. angustifolia. Both Lewis (1962) and De Vos (1999) associated Jacquin's illustration with $I$. stricta and the illustration shows clearly the relatively broad, prominently veined basal leaves and the sheathing upper leaves subtending straight, several-flowered branches. Ker Gawler's varietal name angustifolia is nomenclaturally illegitimate and superfluous because he included the earlier name I. scillaris var. incarnata, this now most likely I. scillaris subsp. latifolia.

Watsonia retusa (Salisb.) Klatt (1882), a combination based on indirect citation of the basionym Ixia retusa Salisb., was regarded by Lewis as a synonym of $I$. micrandra var. confusa. De Vos (1999), however, associated the species with $I$. stricta and we concur. Klatt evidently intended to provide a name for the plant called I. polystachia [sic] by Ker Gawler (1803) in Curtis's botanical magazine but as Ker Gawler specifically mentioned I. retusa Salisbury (1796) in his discussion of the plate in question, Klatt's name must be treated as a combination, but with a basionym that has no known type. Salisbury's brief protologue matches the plant depicted in Curtis's botanical magazine published seven years later in all respects, notably the style branches emerging between the filaments and the tepals twice as long as the perianth tube. But there is no connection between Salisbury's species and the painting.

\section{Representative specimens}

WESTERN CAPE.-3419 (Caledon): Houw Hoek, $2000 \mathrm{ft}[610$ m], (-AA), 25 Nov. 1896, Schlechter 9411 (BM, BOL, K, PRE); Groenland Mtns, Klein Jakkalsrivier, red clay, $2200 \mathrm{ft}[ \pm 700 \mathrm{~m}]$, (AA), 2 Dec. 1982, Viviers 1150 (NBG, PRE); Hermanus, Glenfruin, Onrus Mtn, fynbos on clay, recently burnt, (-AC), 16 Nov. 1991, Barker 305 (MO); Vogelgat, Hermanus, at Fernkloof gate, on shale band, $450 \mathrm{~m},(-\mathrm{AD}), 27$ Nov. 1983, Williams 3523 (NBG, PRE); Drayton Siding, Caledon, (-BA), 16 Dec. 1968, Goldblatt 393 (BOL); roadside between Napier and Elim, (-BD), 5 Dec. 1985, De Vos 2642 (NBG); near Napier, (-BD), 30 Nov. 1933, Salter 4151 (BOL, K); near Baardscheerdersbos, (-DA), 10 Nov. 1985, De Vos 2636 (NBG); Boskloof, Bredasdorp, (-DB), 28 Dec. 1983, Lavranos 21797 (MO, PRE); Bredasdorp, Farm Geelrug, (-DB), 17 Dec. 1975, Barker 10940 (NBG, PRE). 3420 (Bredasdorp): Bredasdorp Mtns, (-CA), Galpin s.n. PRE10463 (PRE).

12. Ixia erubescens Goldblatt in Journal of South African Botany 37: 233 (1971b), as a new name for $I$. crispa L.f.: 91 (1782), a superfluous name for I. undulata Burm.f. Agretta crispa Eckl.: 24 (1827), as a new name for I. crispa L.f. Tritonia thunbergii N.E.Br.: 137 (1929), as a new name for Ixia crispa in Tritonia, non $T$. crispa (L.f.) Ker Gawl. Type: South Africa without precise locality, Thunberg s.n. [LINN 58.25, lecto., designated by Lewis: 173 (1962)].

Plants 120-300 mm high, usually forming clumps, stem simple, rarely 1-branched, sheathed basally by membranous cataphylls. Corm mostly 5-8 mm diam., tunics of fine fibres, usually with large cormlets at base. Leaves $4-6, \pm$ lanceolate, all basal, $\pm 1 / 3$ to $1 / 4$ as long as stem, $2-4(-6) \mathrm{mm}$ wide, main vein well developed, margins or half blade crisped and deeply undulate. Spike erect, lax, secund, weakly flexuose, mostly 6-10-flowered, flowers mostly 15-25 mm apart; bracts mostly green, becoming translucent at tips, turning purple along distal margins, 3-4 mm long, outer with 3 acute- 
attenuate cusps, obscurely 3-veined, inner 2-veined and acutely 2 -toothed. Flowers \pm secund with tepals held \pm vertically, zygomorphic with stamens unilateral, pink, yellow-green in throat edged with dark purple at tepal bases, unscented; perianth tube filiform, 2-3 mm long, tightly clasping style; tepals ovate, spreading \pm at right angles to tube, 8-11 $\times 4-6 \mathrm{~mm}$, outer tepals slightly narrower than inner. Stamens unilateral; filaments filiform, $\pm 2 \mathrm{~mm}$ long, greenish white, drying yellow; anthers oblong, $\pm 1.5 \mathrm{~mm}$ long, yellow, horizontal, becoming slightly pendent, thecae acute and recurved at base, dehiscing incompletely by a narrow slit at base, yellow. Style dividing at base of filaments, style branches 1.5$2.0 \mathrm{~mm}$ long, greenish white, falcate, recurved in distal third, tubular, stigmatic apically. Flowering time: mainly mid-Aug.-mid-Sept.

Distribution and habitat: predominantly a species of near southwestern Western Cape, Ixia erubescens extends from Tulbagh southwards to Stellenbosch and the Caledon District (Figure 8) where its southeasternmost station is at Franskraal, but is absent from the Cape Peninsula. Outlying populations occur on the lower slopes of the Piketberg. The species is most often encountered on heavy clay or granitic alluvium in seasonally damp places, where plants typically form tight clusters through the germination of daughter cormlets. The Piketberg plants are restricted to cooler south-facing slopes where they grow on well-drained clay slopes in the shade of shrubs and small trees, and grow singly rather than in clusters. We concur with the conservation status of I. erubescens, listed by Raimondo et al.(2009) as (LC), least concern, although we note that its range has been historically much reduced through agriculture, especially in the Swartland and Boland.

Diagnosis and relationships: a relatively small species, Ixia erubescens is immediately recognized by the fine corm tunics, the 4-6 narrow, deeply undulate and crisped leaves, usually unbranched stem, and the vertically oriented flower with the stamens unilateral and slightly pendent when fully open. Both Lewis (1962) and De Vos (1999) regarded the flowers as fundamentally actinomorphic with symmetrically arranged stamens and noted that only late in anthesis do the anthers become unilateral and pendulous, simply due to gravity. Our own observations counter this: the stamens are unilateral immediately the flower buds open. We

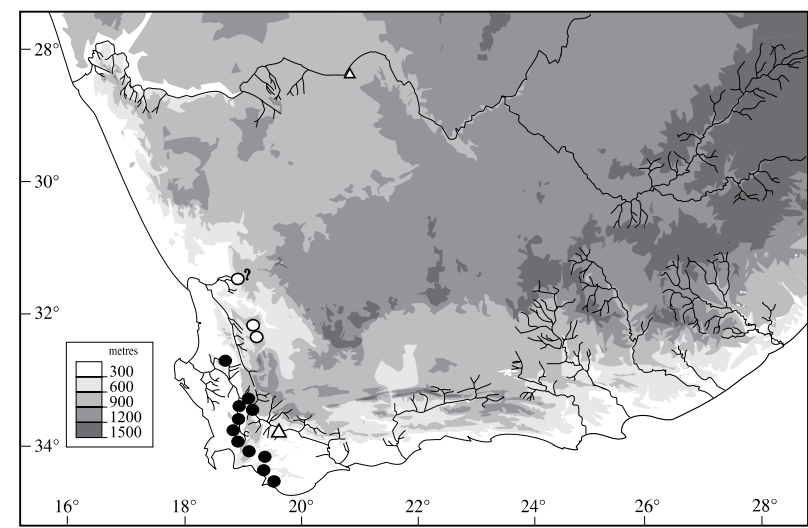

FIGURE 8.-Distribution of Ixia collina, $\Delta$; I. erubescens, •; and I. flagellaris, $\circ$. assume that $I$. erubescens is most closely allied to I. scillaris, which typically has medium to coarse corm tunic fibres, broader leaves, usually with plane margins, and somewhat to substantially larger flowers, also with unilateral stamens, but with a perianth tube up to $4.5 \mathrm{~mm}$ long and tepals up to $14 \mathrm{~mm}$ long (vs. tube 2-3 mm long and tepals 11-12 mm long). Occasional populations of I. scillaris with undulate or crisped leaves are readily distinguished from I. erubescens by their broader leaves, larger flowers, and coarser corm tunic fibres.

The taxonomic history of Ixia erubescens is somewhat confused. Linnaeus fil. (1782) described I. crispa based on C.P. Thunberg's collection but cited the earlier name I. undulata Burm.f. (Burman 1768) (now Tritonia undulata) in synonymy. According to current rules of nomenclature this rendered I. crispa superfluous and therefore illegitimate. The two were often confused by later authors and Baker (1877) used the name Tritonia undulata for the species, not realizing that its type is a different plant. Brown (1929) was the first to realize that I. crispa and I. undulata were different species and transferred I. crispa L.f. to Tritonia under a new epithet, $T$. thunbergii, because he believed that the name $T$. crispa (L.f.) Ker Gawl. (based on Gladiolus crispus L.f.) barred a combination based on Linnaeus fil's I. crispa. On transferring sect. Dichone to Ixia, Lewis (1962) used the name I. crispa for the species. Then Goldblatt (1971b), realizing that I. crispa was superfluous and thus illegitimate, established the new name I. erubescens. Transfer to Ixia of the legitimate T. thunbergii N.E.Br. is prevented by use of that epithet in Ixia by Roemer \& Schultes (1817), their species being a synonym of $T$. securigera Ker Gawl.

\section{Representative specimens}

WESTERN CAPE.-3218 (Clanwilliam): Piketberg, SE-facing slopes of Versveld Pass, damp clay and clay-loam slopes, (-AC), 6 Sept. 2009, Goldblatt \& Porter 13280 (MO, NBG, PRE), 2 Nov. 2011 (fr.), Goldblatt \& Porter 13712 (MO, NBG). 3318 (Cape Town): near Wellington, (-DB). 17 Aug. 1926, Grant 2383 (BOL, PRE); stony hills near Paarl, (-DB), Ecklon 10 'Agretta crispa' (BM, G, M, K, PRE); Elsenberg, (-DD), Grant 2516 (MO, PRE). 3319 (Worcester): Tulbagh, (-AC), Oct. 1916, Marloth 7772 (PRE), Sept. 1915, Marloth 7127 (PRE), 11 Sept. 1926, Grant 2467 (PRE); Tulbaghskloof, etc., Sept. 1830, Ecklon \& Zeyher s.n. 'Agretta crispa' (PRE); near Artois, Tulbagh, (-AC), Aug. 1885, H. Bolus s.n. (BOL26898); Tulbagh, stony clay hillside, 12 Sept. 1950, Esterhuysen 17474 (BOL). 3419 (Caledon): Houw Hoek, (-AA), Aug. 1912, Rogers s.n. (PRE 13553); $3 \mathrm{~km}$ $\mathrm{W}$ of Caledon, $\mathrm{W}$ of road to Badshoogte, $(-\mathrm{AB}), 12$ Oct. 2001, Helme 2294 (NBG); Farm Karwyderskraal, Bot River-Hermanus, (-AC), 15 Sept. 1988, O'Callahan 1784 (NBG); Franskraal, N slope in damp clay, (-CB), 29 Sept. 2005, Ebrahim \& Raimondo CR1075 (NBG).

13. Ixia scillaris L., Species plantarum ed. 2, 1: 52 (1762); Lewis: 173 (1962); De Vos: 78 (1999). Tritonia scillaris (L.) Baker: 163 (1877). Tritonixia scillaris (L.) Klatt: 357 (1882). Type: South Africa, without precise locality or collector [LINN 58.25-digital image!, lecto., designated by Lewis: 174 (1962)].

Plants mostly $150-500 \mathrm{~mm}$ high, stem often with $1-2$, rarely up to 6 branches, sheathed basally by \pm dry, papery cataphylls, often green distally, later turning brown. Corm 10-15 mm diam., tunics of mediumtextured to coarse fibres; cormlets at base conspicuous in subsp. toximontana. Leaves 3-7, mostly in basal fan, upper 1 or 2 partly sheathing the stem, $1 / 3$ to $1 / 2$ 
as long as stem, blade lanceolate or falcate, (3-)6-20 $\mathrm{mm}$ wide, main and sometimes additional veins raised but not thickened, margins markedly thickened in subsp. toximontana. Spike erect, fairly lax, flexuose to \pm straight, secund in 2 ranks, mostly 10-20-flowered; bracts membranous, translucent, sometimes turning purple distally, 3-5 mm long, outer prominently 3-veined and 3-toothed, inner 2-veined and 2-toothed. Flowers \pm nodding with tepals held vertically with lowermost slightly reflexed, zygomorphic with stamens unilateral, bright to pale pink, occasionally white, yellow or white edged in darker pink at tepal bases, lightly rose-scented or unscented; perianth tube filiform, $2.5-4.0 \mathrm{~mm}$ long, tightly clasping style; tepals ovate-elliptic, (8-)10-15 × 5-9 mm, inner 3 slightly larger than outer, lowermost tepal held apart and usually somewhat reflexed. Stamens unilateral; filaments inserted at mouth of tube, filiform, 1.6-3.5 mm long, arching upward near tips, white to pale yellow; anthers oblong-linear, 2.3-4.0 $\mathrm{mm}$ long, horizontal or slightly pendent, thecae recurved and acute at base, dehiscing incompletely from base by narrow slits, yellow. Style dividing \pm opposite base of filaments, branches $\pm 1.5 \mathrm{~mm}$ long, pale yellow, falcate, tubular, stigmatic apically. Capsules \pm obovoid-oblong, 4-5 mm long. Flowering time: mainly mid-Aug.-mid-Oct., occasionally later. Figure 9.

Distribution and habitat: predominantly a species of the west coast and near interior of Western Cape, Ixia scillaris extends from the Cape Peninsula north to the Gifberg and Kobee Mtns, along the coastal plain and mountain ranges parallel to the coast as far inland as the Cedarberg and the Pakhuis-Nardouw Mtns. Isolated populations occur in the Spektakel Mtns in northern Namaqualand, Northern Cape (Figure 10). Plants grow

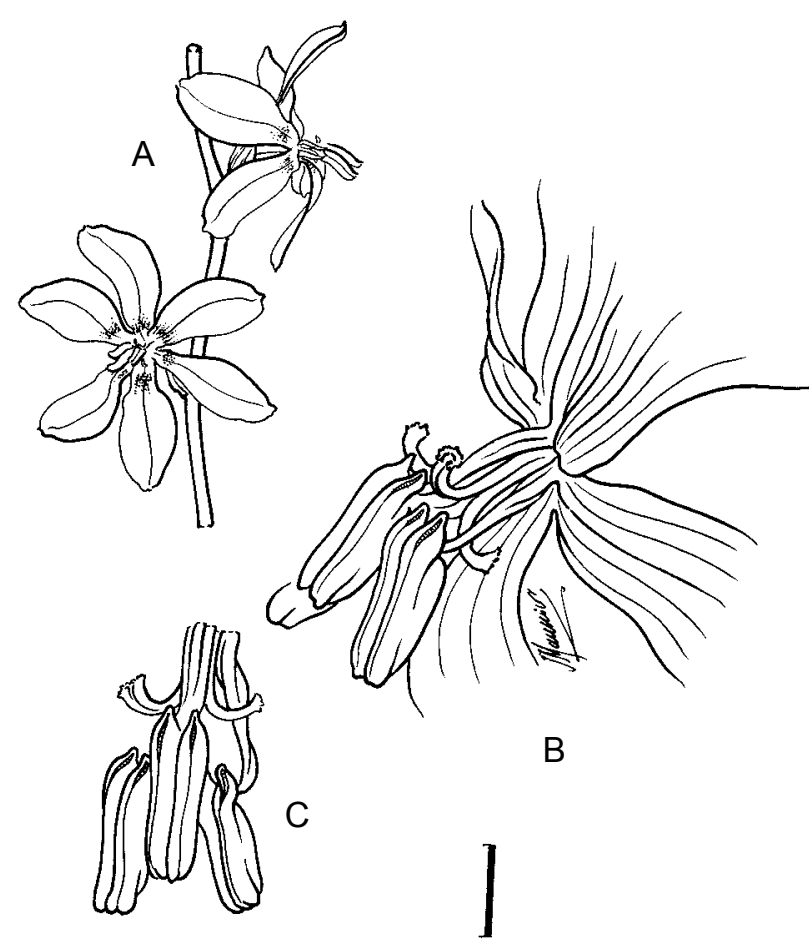

FIGURE 9.-Ixia scillaris subsp. latifolia, Goldblatt \& Manning 13482 (NBG). A, flowers; B, stamens and style branches, side view with base of tepals; C, stamens and style branches, dorsal view. Scale bar: $10 \mathrm{~mm}$. Artist: John Manning.

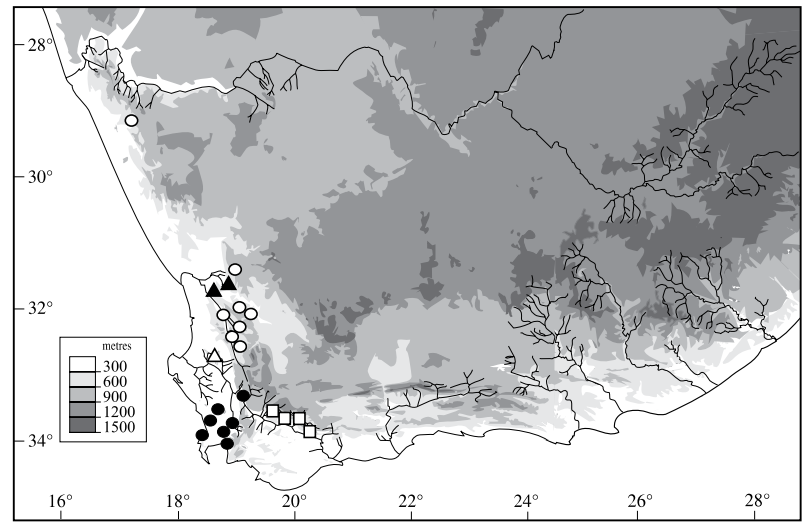

FIGURE 10.-Distribution of Ixia scillaris subsp. latifolia, ○.; subsp. scillaris, $\bullet$; subsp. toximontana, $\mathbf{\Delta} ;$ I. simulans, $\square$; and I. tenuis, $\Delta$.

on a variety of soils but most commonly on heavy clays derived from shale or granite. With so wide a range its conservation status (LC), Least Concern, seems appropriate. The range of subsp. scillaris is, however, much reduced and may be Vulnerable (VU).

Studies of the floral biology of Ixia scillaris (Goldblatt et al. 2000) show the flowers are adapted for buzz pollination by anthophorine bees. Pollen remains in the anthers until vibrated at high frequency by the wings of visiting bees. Unusual for flowers with this pollination strategy, the pollen falls back into the centre of the flower through narrow slits at the base of the anthers. Like all species of sect. Dichone, the flowers do not produce nectar.

Diagnosis and relationships: the most common and widespread species of sect. Dichone, Ixia scillaris is recognized primarily by the nodding flower with vertically oriented tepals with unilateral, slightly pendent and often relatively long anthers, combined with a fan of 3-7 basal leaves, (3)6-20 mm wide. Related I. erubescens has narrow, \pm falcate leaves, $2-4(-6) \mathrm{mm}$ wide, with closely crisped margins, and is a smaller plant with smaller flowers, the tepals $8-11 \times 4-6 \mathrm{~mm}$ and anthers $2.0-2.5 \mathrm{~mm}$ long vs. tepals mostly $10-15 \times 5-9 \mathrm{~mm}$ and anthers 3-4 mm long in I. scillaris. Apparently closely allied Ixia simulans, with half to fully nodding flowers and unilateral stamens with pendent anthers, has a single basal, \pm linear foliage leaf and a second leaf sheathing the stem for most of its length. Ixia tenuis from the Piketberg is a particularly slender species with small corms with finely fibrous tunics, just three, narrow, softtextured leaves and relatively small flowers with dark magenta tepals. I. tenuis grows in a habitat unique for species allied to I. scillaris, seeps on sandstone rocks, growing in moss in soils less than $10 \mathrm{~mm}$ deep.

Variation: Typical Ixia scillaris from Darling and Tulbagh to the Cape Peninsula has (4)5-7 relatively narrow leaves, mostly 5-8 mm wide, with $3-5$ secondary veins conspicuous only when dry, mostly branched stems (rarely with up to 7 branches), and moderately dense spikes with flowers spaced $8-12 \mathrm{~mm}$ apart. The flowers are relatively small, with tepals $8-10 \times 4-5 \mathrm{~mm}$ and \pm symmetrically arranged, although the lowermost tepal is held slightly apart and recurved, and anthers 
2.0-2.8 mm long. In contrast, plants from the Olifants River Valley and low elevations in the Cedarberg ranging into the Bokkeveld and Spektakel Mtns are always taller, with 2-4, broader leaves mostly 15-20 mm wide, usually with at least two conspicuous secondary veins in addition to the main vein, stems simple or with 1(2) branches, and lax spikes with flowers distantly spaced, 15-25 $\mathrm{mm}$ apart. The flowers are larger, with tepals 14-16 $\times 5-9 \mathrm{~mm}$, the upper tepals overlapping and separated from the three lower tepals, and anthers 3.2$4.0 \mathrm{~mm}$ long (Table 1). Although Lewis (1962) noted the variation in leaf number and venation between the southern and northern populations she preferred not to recognize the two forms taxonomically as she believed them to intergrade in leaf form and number to some extent. She did not, however, note that the distinction was accompanied by differences in size of the flowers, which we consider as significant as the leaf differences.

A third set of divergent populations occurs on the Gifberg-Matsikamma Mtn complex. These consist of unusually small plants, seldom exceeding $150 \mathrm{~mm}$ in height, with small flowers (tepals $\pm 8 \times \pm 4 \mathrm{~mm}$, anthers $\pm 2 \mathrm{~mm}$ long), thus like those of the southern populations of Ixia scillaris but with just three leaves (rarely two in depauperate individuals), recalling the northern populations, at least in leaf number, although the leaves are shorter and narrower.

Our taxonomic solution to the variation in Ixia scillaris is to recognize the three sets of populations as separate subspecies, those of the larger-flowered, northern populations as subsp. latifolia and the Gifberg-Matsikamma populations as subsp. toximontana. We choose subspecies rank because of the small overlap between some populations of each subspecies and the comparatively small degree of difference between them relative to that between species of sect. Dichone.

In addition to these major variants, Lewis recognized populations with undulate leaves as var. subundulata. The type of the variety is from east of Pakhuis Pass (Barker 4727) and there are several more collections from this area. Plants with undulate leaves also occur locally near Tulbagh. Flowers of the Pakhuis-northern
Cedarberg have the relatively large flowers that correspond with subsp. latifolia whereas those from the south have smaller flowers of matching subsp. scillaris. We see no value in recognizing undulate-leaved plants taxonomically. Undulate leaf margins have evidently evolved independently in different parts of the range of Ixia scillaris.

History: the taxonomic history of Ixia scillaris begins with a brief polynomial entry in A. van Royen's (1740) Florae leydensis prodromus, an account of the plants grown in the botanical garden of Leiden University. Linnaeus (1753), in the first edition of the Species plantarum, adopted van Royen's species and, using his actual phrase name, provided the specific epithet ramosus to the description Gladiolus caule ramoso, foliis linearibus. The specimen is still at the Leiden Herbarium. Then, in the second edition of his Species plantarum, Linnaeus (1762) described Ixia scillaris, based on a specimen in his own herbarium. Evidently Linnaeus simply did not relate this specimen to the earlier name, although he may well have seen Van Royen's specimen or the living plants when he was in The Netherlands some 15 years earlier. Gladiolus ramosus was forgotten for many years but was listed by Ker Gawler (1827) as a synonym of Melasphaerula graminea (L.f.) Ker Gawl. and by Lewis et al. (1962) as a synonym of the same species under the name $M$. ramosa (Burm.f.) N.E.Br. [the basionym for $M$. ramosa is Phalangium ramosum Burm.f. (1768) and has no apparent connection with $G$. ramosus L.]. F.W. Klatt (1894) cited G. ramosus L. as the basionym for his combination Melasphaerula ramosa (L.) Klatt, an action that rendered Brown's later combination $M$. ramosa (Burm.f.) N.E.Br. a homonym. Transfer of G. ramosus to Ixia is prevented by I. ramosa Ker Gawl., a replacement name for the homonym I. scillaris Thunberg (1783), now Geissorhiza scillaris A.Dietr. (Goldblatt 1985). Thunberg was uncertain of the identity of I. scillaris L., which he cited as a possible synonym of $I$. pentandra L.f.

\section{Key to subspecies}

1a Leaves (4-)5-7, lower two up to $10 \mathrm{~mm}$ wide, usually lanceolate and lacking submarginal veins (margins rarely

TABLE 1.- Significant taxonomic features of the subspecies of Ixia scillaris and allied I. tenuis. Observations are taken from living plants or from well preserved specimens, bearing in mind that floral features may shrink up to $20 \%$ of original size, depending on the care with which specimens are prepared.

\begin{tabular}{|c|c|c|c|c|}
\hline Character & Subsp. scillaris & Subsp. latifolia & Subsp. toximontana & Ixia tenuis \\
\hline Corm tunic texture & medium & medium to coarse & medium to coarse & fine \\
\hline Leaf number & $(4-) 5-7$ & 3 or 4 & $(2) 3(4)$ & $3(2)$ \\
\hline Leaf shape; width (mm) & lanceolate; $5-8$ & usually falcate; $8-25$ & usually falcate; $3-8$ & linear; $1.5-3.0$ \\
\hline Prominent leaf veins & $\begin{array}{l}3-5 \text {, only main when } \\
\text { alive }\end{array}$ & $\begin{array}{l}\text { usually } 2 \text { or } 3 \text { plus main } \\
\text { vein }\end{array}$ & $\begin{array}{l}\text { main vein, secondary veins } \\
\text { pair hyaline when alive, raised } \\
\text { when dry }\end{array}$ & only main vein when dry \\
\hline Margins & not raised & hardly raised & raised and thickened & not raised \\
\hline Perianth tube length (mm) & $2.5-4.0$ & $3.5-4.0$ & \pm 3 & $3.0-3.5$ \\
\hline Outer tepals $(\mathrm{mm})$ & $8-10 \times 4-5$ & $10-15 \times 5-9$ & $\pm 8 \times 4$ & $8-9 \times 4-5$ \\
\hline Stamen filaments (mm) & $1.5-2.0$ & $2.0-3.5$ & $1.0-1.6$ & \pm 2 \\
\hline Anthers (mm) & mostly $2-3$ & $3-4$ & $1.6-2.5$ & $2.0-2.5$ \\
\hline Bracts $(\mathrm{mm})$ & $3.5-4.8$ & $4-5$ & $3-4$ & $2-3$ \\
\hline Flowers per main spike & mostly $10-15$ & mostly $15-20$ & mostly $10-15$ & mostly 4-10 \\
\hline Spike internodes (mm) & $6-12$ & $14-20$ & $8-12$ & $10-15$ \\
\hline
\end{tabular}


undulate); tepals $8-10 \times 4-5 \mathrm{~mm}$; anthers $2.0-3.5 \mathrm{~mm}$

long $\ldots \ldots \ldots \ldots \ldots \ldots \ldots \ldots \ldots \ldots \ldots \ldots$ subsp. scillaris

1b Leaves $2-4$, lower two $3-25 \mathrm{~mm}$ wide, usually \pm falcate, sometimes with pair of prominent secondary veins, these often submarginal (margins sometimes undulate to crisped, then without prominent secondary veins); tepals 8-15 × 4-9 mm; anthers 2-4 mm long:

2a Leaves (9-)12-25 mm wide; tepals 10-15 × 5-9 mm; anthers mostly $3-4 \mathrm{~mm}$ long . . . . . . . . . subsp. latifolia

2a Leaves 3-8 mm wide; tepals $\pm 8 \times 4 \mathrm{~mm}$; anthers $1.6-2.5$ $\mathrm{mm}$ long $\ldots \ldots \ldots \ldots \ldots \ldots$ subsp. toximontana

\section{3a. subsp. scillaris}

Gladiolus ramosus L.:37 (1753) [non Ixia ramosa Ker Gawl., (1802) = Geissorhiza scillaris A. Dietr.]. Melasphaerula ramosa (L.) Klatt: 203 (1894), epithet misapplied to Melasphaerula. Type: South Africa, without precise locality or collector, ex hort. Leiden, A. van Royen s.n. (L: Herb. Royen, holo.- digital image!).

Ixia pentandra L.f.: 92 (1782). Agretta pentandra (L.f.) Eckl. Type: South Africa, [Western Cape], near Groene Kloof, without date, Thunberg s.n. (UPSTHUNB, holo.-microfiche!).

Plants mostly 150-350 mm high, stem usually branched, sometimes with up to 6 branches. Corm mostly $12-14 \mathrm{~mm}$ diam. Leaves (4-)5-7, lanceolate to sword-shaped or subfalcate, margins sometimes undulate, 5-8 $\mathrm{mm}$ wide, upper leaves progressively smaller than lower. Spike mostly 10-15-flowered, flowers mostly 6-12 mm apart; bracts $3.5-4.8 \mathrm{~mm}$ long. Flowers pale to deep pink, darker at base of tepals, not pale in throat, perianth tube $2.5-4.0 \mathrm{~mm}$ long, tepals subequal, upper 5 tepals overlapping and evenly disposed with lower laterals extended horizontally, lowermost held apart, directed forward above base and then downward, $8-10 \times 4-5 \mathrm{~mm}$, inner narrower than outer. Filaments $1.5-2.0 \mathrm{~mm}$ long, anthers mostly $2-3 \mathrm{~mm}$ long. Flowering time: mainly mid-Sept.-late Oct. (rarely in late Aug.).

Distribution and habitat: restricted to the southwestern Western Cape, subsp. scillaris extends from Tulbagh and Darling to the Cape Peninsula and Somerset West (Figure 10). The only record outside this area, a collection from Hawston near Bot River, Wilman s.n. NBG, is the Clanwilliam form of Ixia scillaris, subsp. latifolia, and we assume the label is incorrect. Subsp. scillaris is common and fairly conspicuous where it occurs, mainly on granite-derived sandy gravels.

Diagnosis: subsp. scillaris can be distinguished by the several, (4)5-7, leaves mostly 5-8 $\mathrm{mm}$ wide, in which only the main is prominent when alive (Table 1). The flowers are slightly smaller than in subsp. latifolia, with tepals $8-10 \times 4-5 \mathrm{~mm}$, the lowermost slightly recurved and held separate from the upper five. The anthers are also slightly smaller than in subsp. latifolia, 2-3 mm vs. mostly 3-4 mm long.

\section{Representative specimens}

WESTERN CAPE.-3318 (Cape Town): Groenekloof [Mamre] and hills nearby, (-AD), Oct., Ecklon \& Zeyher Irid 241 (MO); Mamre Hills (-AD), 26 Sept. 1941, Compton 11768 (MO, NBG); Cape Town, above Camps Bay, (-CD), 26 Oct. 1944, Barker 3214 (MO, NBG); Lions Head, (-CD), H. Bolus 2826 (BM, BOL, K); Paarl Mtn, near Taal Monument, (-DA), 17 Oct. 1986, Goldblatt 7919 (MO, PRE);
Langverwacht above Kuilsrivier, sandy west-facing slope, (-DC), 24 Aug. 1973, Oliver 4362 (MO, NBG, PRE). 3319 (Worcester): fields near Tulbagh, leaves undulate, (-AC), Sept. 1916, Marloth 7772 (PRE). 3418 (Simonstown): Helderberg, 240 m, (-BB), 17 Oct. 1948, Parker 4360 (BOL, MO, NBG); Sir Lowry's Pass, (-BB), Schlechter 5370 (BM, BOL, G, K); Vergelegen, Somerset West, (-BB), 13 Oct. 1982, Viviers 709 (PRE).

13b. subsp. latifolia Goldblatt \& J.C.Manning, subsp. nov.

TYPE.-Western Cape, 3218 (Clanwilliam): Cedarberg, Nieuwoudt Pass, burned slopes, (-BD), Goldblatt \& Porter 13475 (NBG, holo.; K, MO, PRE, iso.)

I. reflexa Andr.: t. 14 (1797). I. rotata [Ker Gawl.] in Andrews: 3 (1801), nom. illeg. superf. pro I. reflexa Andr. [Ker Gawl. is the author of this publication (Stafleu \& Cowan 1979), but internal evidence for authorship is lacking]. Type: South Africa, without precise locality, cultivated in Great Britain by Messrs. Lee \& Kennedy and sent to them by J. Pringle but possibly collected by F. Masson or W. Paterson (Gunn \& Codd 1981), illustration in Andrews, The botanist's repository 1: t. 14 (1797) — no preserved specimen known.

I. polystachya var. incarnata Andr.: t. 128 (1800). Type: South Africa, without precise locality, cultivated in Great Britain by Messrs. Lee \& Kennedy and sent to them by J. Pringle but possibly collected by Francis Masson or William Paterson (Gunn \& Codd 1981), illustration in Andrews, The botanist's repository 2: t. 128 (1800)—no preserved specimen known.

I. scillaris var. angustifolia Ker Gawl. in Sims: sub t. 542 (1801), nom. illegit. superf., including type of $I$. polystachya var. incarnata Andr. Type: not designated, two illustrations cited.

I. scillaris var. latifolia Ker Gawl. in Sims: t. 542 (1801). Type: South Africa, without precise locality, cultivated in Great Britain, Masson s.n., illustration in Curtis's Botanical Magazine 15: t. 542 (1801)—no preserved specimen known.

I. scillaris var. subundulata G.J.Lewis: 177 (1962). Type: Western Cape, Klipfonteinrand, 13 Sept. 1947, Barker 4727 (NBG, holo.!, BOL!, iso.).

Plants mostly $300-500 \mathrm{~mm}$ high, stem simple or with 1 or 2(3) branches. Corm mostly 14-20 mm diam. Leaves 3 or 4 , sometimes an additional leaf present at base of a branch, lower 2 or 3 broadly falcate, (9-)12-25 $\mathrm{mm}$ wide, usually with pair of conspicuous secondary veins and often well developed submarginal vein, upper leaf/leaves smaller, margins plane or undulate, then without well developed secondary veins. Spike mostly 15-20-flowered, flowers mostly 14-20 mm apart; bracts 4-5 mm long. Flowers pale to deep pink or white, then flushed pale pink near tepal bases; perianth tube 3.5-4.0 $\mathrm{mm}$ long; tepals subequal, upper 3 held close together, lowermost held slightly apart arched backward, 10-15 $\times$ 5-9 mm. Filaments 2.0-3.5 mm long, broader at base; anthers 3-4 mm long. Style branches $\pm 2.5 \mathrm{~mm}$ long, almost reaching anther bases. Flowering time: mainly mid-Aug.-mid-Sept., rarely to early Oct. at higher elevations. Figure 9. 
Distribution and habitat: subsp. latifolia is centred in the Olifants River valley and lower elevations of the surrounding Cedarberg, Pakhuis-Bidouw Mts, extending from near Citrusdal to Bulshoek and locally in the Bokkeveld Mtns. Isolated populations occur on the Spektakel Mtns of northern Namaqualand, a notable disjunction (Figure 10). It is replaced on the Gifberg/ Matsikamma Mtns by subsp. toximontana. Plants favour rocky situations, mostly in sandy ground. Subsp. latifolia is common throughout its range, but it flowers well only after fire or clearing of the veld. The spring following a fire plants are often seen in masses where before the fire none were evident.

Diagnosis and variation: subsp. latifolia is distinguished by the presence of 3 or 4 leaves and by the relatively larger flowers, the tepals $10-15 \times 5-9 \mathrm{~mm}$ and anthers 3-4 mm long (vs. tepals 8-10 $\times 4-5$ and anthers 2-3 m long). The upper three tepals are held more closely together than the lower three and the lowermost is conspicuously recurved.

Variation in leaf morphology in subsp. latifolia is notable. Plants from Clanwilliam and nearby have a conspicuous submarginal vein, but those from elsewhere have a prominent secondary vein pair distant from the margins, and plants from the Spektakel Mtns of Namaqualand show no prominent secondary veins and appear thinner in texture. No other feature seems to set the Spektakel population apart. Populations east of the Pakhuis-Nardouw Mtns have leaf margins slightly to markedly undulate and without conspicuous veins apart from the main vein.

\section{Representative specimens}

NORTHERN CAPE.-2917 (Springbok): 14 miles [ $\pm 21 \mathrm{~km}$ ) SW of Springbok, (-DA), Acocks 19439 (NBG, PRE); Spektakel Pass, E-facing slope near the top, (-DA), 26 Sept. 1974, Goldblatt 2804 (MO, PRE). Spektakel, (-DA), 25 Aug. 1941, Esterhuysen 5853 (BOL). 3119 (Calvinia): between Nieuwoudtville and Oorlogskloof, (-?AC), Aug. 1941, Leipoldt (BOL, PRE).

WESTERN CAPE.-3218 (Clanwilliam): Zeekoe Vlei, (-BA), 19 Aug. 1896, Schlechter 8580 or 8500 (BM, G, K, MO, PRE); Clanwilliam, (-BB), 10 Sept. 1949, Steyn 516 (MO, NBG); Farm Kransvlei, rocky sandstone ground, (-BB), 25 Aug. 2009, Goldblatt \& Manning 13482 (MO, NBG). 3219 (Wuppertal): Biedouw Valley on road to Wuppertal, (-AA), 7 Sept. 1992, Goldblatt \& Manning 9409 (MO, NBG, PRE); Brandewyn River, (-AA), 29 Aug. 1941, Barker 1327 (BOL, NBG); Cedarberg, Langrug, (-AC), 12 Sept. 1982, Viviers 579 (PRE); Clanwilliam Dam to Algeria, (-AC), 9 Sept. 1976, Goldblat 2567 (MO, PRE); banks of the Olifants River and at Villa Brakfontein, (-BA), without date, Ecklon \& Zeyher Irid. 243 or s.n. (G, MO, PRE, SAM). Without precise locality: Grey's Pass to Clanwilliam, Sept. 1941, Leipoldt 3832 (BOL, PRE)

13c. subsp. toximontana Goldblatt \& J.C.Manning, subsp. nov.

TYPE.-Western Cape, 3118 (Vanrhynsdorp): Gifberg, summit plateau in sandy ground over rocky pavement, common after fire, (-DC), 1 Nov. 2011, Goldblatt \& Porter 13703 (NBG, holo.; K, MO, PRE, iso.).

Plants $120-250 \mathrm{~mm}$ high, simple or with 1 or 2 , rarely 3 branches. Corms globose-conic, mostly 15-18 $\mathrm{mm}$ at widest diam., tunics of hard, coarse fibres; bearing conspicuous cormlets at base. Leaves (2)3(4), all \pm basal, mostly 3-8 mm wide, main vein prominent, secondary pair of veins hyaline when alive, raised when dry, margins appearing thickened when dry. Spike mostly 10-15-flowered, flowers mostly 8-12 mm apart; bracts $3-4 \mathrm{~mm}$ long. Flowers opening pale pink turning deep pink next day, tepal bases yellow edged dark pink, throat pale yellow, perianth tube $\pm 3 \mathrm{~mm}$ long, tepals subequal, $\pm 8 \times 4 \mathrm{~mm}$ lowermost held slightly apart and arched backward. Filaments 1.0-1.6 mm long, anthers 1.6-2.5 mm long. Style branches $\pm 1.5 \mathrm{~mm}$ long, almost reaching anther bases. Flowering time: late Sept.-midNov.

Distribution: restricted to the Gifberg and Matsikamma Mtn complex of northern Western Cape, subsp. toximontana grows in shallow, sandy ground overlying sandstone pavement (Figure 10). The habitat is permanently wet in the rainy winter and early spring months but becomes dry by the end of September and remains so though the summer and autumn. Most of its range is virtually intact and pristine at present.

Diagnosis: subsp. toximontana is distinguished in Ixia scillaris by its low stature, seldom exceeding 150 $\mathrm{mm}$. combined with relatively small flowers and only 2 or 3 leaves, these short and relatively narrow, 3-8 $\mathrm{mm}$ wide. The flowers have tepals $\pm 8 \times 4 \mathrm{~mm}$ and anthers $\pm 2.3 \mathrm{~mm}$ long, smaller than in subsp. latifolia or subsp. scillaris (Table 1). In their small size they recall subsp. scillaris rather than subsp. latifolia, in whose range it is nested. The particularly small size of all parts may be an adaptation to the habitat, nutrient-poor, shallow, sandy ground.

\section{Representative specimens}

WESTERN CAPE--3118 (Vanrhynsdorp): Gifberg, (-DC), 17 Sept. 1961, Barker 9578 (NBG, PRE); top of Gifberg, (-DC), 23 Sept. 1962, Rycroft 2548 (NBG); summit of Gifberg Pass, open spaces and shallow rock pans, (-DC), 9 Oct. 1973, Hall 4493 (NBG), 11 Oct. 1973, Bayliss 6153 (MO); Matsikammaberg, on recently burnt sandstone, (-DB), 11 Nov. 1985, Snijman 963 (NBG).

\section{Ixia tenuis Goldblatt \& J.C.Manning, sp. nov.}

TYPE.-Western Cape, 3218 (Clanwilliam): Piketberg, Farm Noupoort, in wet mossy seeps on sandstone rocks, (-DC), 2 Nov. 2011, Goldblatt \& Porter 13710 (NBG, holo.; K, MO, PRE, iso.).

Plants slender, $180-350 \mathrm{~mm}$ high, stem simple or rarely 1-branched. Corms globose, 7-10 $\mathrm{mm}$ diam., tunics of fine fibres. Leaves mostly 3(2), occasionally 4 but then this very reduced in size, \pm linear to narrowly sword-shaped, 1/4-1/2 as long as stem, mostly 1.5-3.0 $\mathrm{mm}$ wide, relatively soft-textured, pale grey-green, when alive main vein slightly raised (appearing thickened when dry), margins not raised (rarely undulate, then blade up to $5 \mathrm{~mm}$ wide-Barker 4671, 5764, see comments below). Spike mostly 4-10-flowered, flowers mostly $10-15 \mathrm{~mm}$ apart; bracts $2-3 \mathrm{~mm}$ long. Flowers deep magenta with tepal bases yellow edged with darker magenta (or pale pink or white-Barker 4671, 5764), throat pale yellow, perianth tube $3.0-3.5 \mathrm{~mm}$ long, expanded in upper $1 \mathrm{~mm}$; tepals $8-9 \times 4-5 \mathrm{~mm}$, oriented vertically but with lowermost tepals recurved and \pm horizontal. Stamens unilateral; filaments $\pm 2 \mathrm{~mm}$ long; anthers 2.0-2.5 mm long. Style branches $\pm 1 \mathrm{~mm}$ long, reaching to \pm middle of filaments. Flowering time: mid-Oct.-mid-Nov. 
Distribution and habitat: known from just a handful of sites, Ixia tenuis is restricted to rocky, sandstone habitats in the Piketberg Mtns, mostly at elevations of 650-800 m (Figure 10). We collected the type population on the Farm Noupoort on south-trending slopes of a rocky hill growing in wet moss on shallow soil on sandstone outcrops. The remaining collections lack detailed habitat notes. We note that the undulate-leaved variant (see below) is from the foot of the Piketberg Range and blooms earlier, in September. The species is rare, and at present merits a conservation status of Vulnerable (VU), but we see no imminent threat.

Diagnosis: Ixia tenuis is distinguished from the widespread I. scillaris by its very slender habit, the stems rarely branched, usually three, narrow leaves, mostly $1.5-3.0 \mathrm{~mm}$ wide, and relatively small flowers with tepals $8-9 \times 4-5 \mathrm{~mm}$ and anthers $2.0-2.5 \mathrm{~mm}$ long (Table 1). The corms are also relatively small, mostly less than $10 \mathrm{~mm}$ in diameter and with relatively fine tunic fibres. Corms of $I$. scillaris are larger, typically 12-18 (rarely only 10) $\mathrm{mm}$ in diameter, with relatively coarse tunic fibres, and the species has broader leaves, mostly 8-25 mm wide. We provisionally include collections by W.F. Barker (Barker 4671 and 5764) from De Hoek and flowering in September here. These specimens have slightly broader but shorter leaves than typical $I$. tenuis and have undulate margins. This variant, which we have not seen alive, was included by Lewis (1962) as I. scillaris var. subundulata, the type of which we include in I. scillaris subsp. latifolia.

\section{Representative specimens}

WESTERN CAPE.-3218 (Clanwilliam): Piketberg Mtns, S side of large boulders, $2500 \mathrm{ft}$ [800 m], (-DC), 3 Nov. 1951, Barker 7584 (NBG); Piketberg, top of mountain on Versfeld Pass, $650 \mathrm{~m},(-\mathrm{DC})$, 4 Nov. 1988, Steiner 1863 (NBG); De Hoek, Piketberg, leaf margins undulate, (-DC), 28 Sept. 1943, Barker 2560 (NBG), (flowers white), 12 Sept. 1947, Barker 4671 (NBG), 10 Sept. 1949, Barker 5764 (NBG).

15. Ixia flagellaris Goldblatt \& J.C. Manning, sp. nov.

TYPE.-[Western Cape]. 3219 (Wuppertal): Heuningvlei, Groot Koupoort, common on wet sandy flats burnt last summer, $3150 \mathrm{ft}[ \pm 960 \mathrm{~m}],(-\mathrm{AA}), 11$ Oct. 1975, Kruger 1687 (NBG, holo.; PRE, iso.).

Plants 150-330 mm high, stem simple, rarely with 1 branch. Corm small, up to $10 \mathrm{~mm}$ diam., bearing stolons up to $50 \mathrm{~mm}$ long from base, with a large terminal cormlet up to $5 \mathrm{~mm}$ diam., tunics finely fibrous to moderately coarse. Leaves 4, uppermost sheathing for most of its length, foliage leaves with blades narrowly sword-shaped to falcate, $\pm 1 / 3$ as long as stem, mostly 2-4 mm wide, main vein prominent, margins slightly thickened. Spike mostly 5-9-flowered; bracts translucent with purple veins, 3-4 mm long, outer 3-veined, acutely 3-toothed, inner slightly shorter than outer, 2-veined and 2-toothed. Flowers evidently zygomorphic, nodding with tepals vertical, pink, throat and tepal bases yellow edged with deep pink; perianth tube filiform, $\pm 3 \mathrm{~mm}$ long; tepals ovate, $\pm 9.0 \times 4.5 \mathrm{~mm}$. Stamens evidently unilateral; filaments slightly flattened, $\pm 2 \mathrm{~mm}$ long; anthers oblong-orbicular, $\pm 3 \mathrm{~mm}$ long, yellow, thecae recurved and acute at base, splitting incompletely from base. Style dividing at base of filaments, branches \pm 1.8 $\mathrm{mm}$ long, falcate, slender. Flowering time: Oct. and Nov.

Distribution and habitat: restricted to middle and upper elevations in the Cedarberg, Ixia flagellaris is currently known from just two collections from the Cedarberg, one from Heuning Vlei in the north and the other from Sneeuberg in the south (Figure 8). The type collection was made the season after a fire. The species evidently grows on damp flats, most likely on peaty sandstone ground, but this remains to be established. A collection from Kobee Pass (see below) is provisionally included here.

Diagnosis and relationships: the outstanding feature of Ixia flagellaris is the corm, which is remarkable in the I. scillaris complex in the finely fibrous corm tunics and in the production of slender stolons (Latin: flagellae) up to $50 \mathrm{~mm}$ long, each terminating in a relatively large cormlet. No other member of sect. Dichone produces stolons although they are known in a few species of sect. Ixia and Morphixia (Goldblatt \& Manning 2011). I. flagellaris otherwise accords closely with I. scillaris subsp. toximontana, notably in its relatively low stature, 150-330 mm high, and small flowers with tepals \pm 9.0 $\times 4.5 \mathrm{~mm}$, but differs in lacking prominent, thickened leaf margins.. The late flowering and moist habitat, seeps and marshy sites, are unusual for the complex, although known in the Piketberg species, I. tenuis. Plants from Kobee Pass (Hall 4517) cited below may belong here as they have fine corm tunics and unthickened leaf margins but they evidently do not produce stolons. Their exact status remains uncertain.

\section{Representative specimens}

WESTERN CAPE.-3219 (Wuppertal): Cedarberg, Sneeuberg, Duiwelsgat Kloof, damp places, (-AC), 24 Nov. 1982, Viviers 789 (NBG). Provisionally included here: 3119 (Calvinia): summit of Kobee Pass, open spaces in shallow pans, (-CA), 14 Oct. 1973, Hall 4517 (NBG).

\section{Ixia simulans Goldblatt \& J.C. Manning, sp. nov.}

TYPE.-Western Cape, 3320 (Montagu): Langeberg Mtns, gorge near Montagu hot springs above Keisie River, on steep rocky sandstone slopes, $(-\mathrm{CC}), 1$ Sept. 2007, Goldblatt \& Porter 12946 (NBG, holo., K, MO, PRE, iso.).

Plants $40-100 \mathrm{~cm}$ high, stems usually simple, rarely with a single branch, sheathed basally by membranous cataphylls. Corm $\pm 10 \mathrm{~mm}$ diam., tunics of fine, netted fibres. Leaves 2(3), lower 1(2) with narrowly swordshaped to linear blade with single prominent vein, $\pm 1 / 2$ as long as stem, $1.5-6.5 \mathrm{~mm}$ wide, margins thickened and slightly raised, hyaline when dry; upper leaf sheathing lower $1 / 2$ of stem, free and unifacial distally. Spike erect, fairly lax, weakly flexuose or straight, 4-8-flowered; bracts membranous, translucent, purple at tips, \pm $4 \mathrm{~mm}$ long, outer usually with 3 prominent veins and 3-toothed, inner 2-veined and forked at apex. Flowers \pm nodding with tepals held vertically, zygomorphic with stamens unilateral, bright pink (rarely pale pink), white at tepal bases, unscented; perianth tube filiform, \pm 4.5 $\mathrm{mm}$ long, tightly clasping style; tepals spreading, ovateelliptic, (10-)12-14 × 5-6 mm, inner whorl slightly larger than outer. Stamens unilateral, filaments inserted 
at mouth of tube, filiform, $\pm 2.5 \mathrm{~mm}$ long, white, anthers oblong, 2.0-2.5 mm long, yellow, horizontal or slightly pendent, thecae acute and slightly recurved at base, dehiscing incompletely from base by narrow slits. Style dividing opposite lower $1 / 3$ of filaments, branches \pm $1.3 \mathrm{~mm}$ long, white, tubular, falcate, stigmatic apically. Flowering time: mid-Aug.-mid-Oct. Figure 11.

Distribution and habitat: Ixia simulans is currently known from just four collections, three from the western Langeberg, between Dassieshoek near Robertson and Swellendam, and one from Lemoenpoort in the northern foothills of the Riviersonderend Mtns (Figure 10). Records are all from stony ground, and at the Keisie River Gorge near Montagu hot springs plants grew on steep, rocky, south-facing slopes. Plants are rooted in shallow sandy soil, often growing in clumps of Restionaceae. All known localities for I. simulans are in virtually undisturbed montane vegetation and we see no threat to the species: a conservation status of Least Concern (LC) seems appropriate.

Diagnosis and relationships: Ixia simulans is a surprising novelty given that the western Langeberg has been botanized for over two centuries and intensely so in the past 50 years. The flowers closely resemble those of I. scillaris in general appearance and have unilateral, horizontal to slightly pendent anthers that dehisce incompletely by narrow slits near the base. I. simulans differs from I. scillaris most conspicuously in its single, or rarely two, long, basal leaves with \pm linear blades $1.0-4.5 \mathrm{~mm}$ wide, spikes of only $4-8$ flowers, relatively short floral bracts $\pm 4 \mathrm{~mm}$ long and the spreading, subequal tepals, those of the inner whorl being slightly shorter than the outer. The tepals are inclined and all held in the same plane whereas those of I. scillaris are always held vertically and the lowermost tepal is weakly to strongly recurved and held apart from the other five tepals.

The range of Ixia simulans and I. scillaris complement one another: I. scillaris extends from the Cape Peninsula and Somerset West in the south through the Olifants River Valley, Cedarberg-Pakhuis Mtn complex to the Bokkeveld Mtns, and locally well to the north in the Spektakel Mtns west of Springbok whereas I. simulans occurs well to the east of this line in the western Langeberg.

\section{Representative specimens}

WESTERN CAPE.-3319 (Worcester): Lemoenpoort, rocky slopes, (-CD), 18 Aug. 1990, Bruyns sub Perry 3766 (NBG); Dassieshoek near Robertson, (-DB), 27 Aug. 2006, Goldblatt \& Porter 12724 (MO, NBG, PRE). 3320 (Montagu): Langeberg Mtns, Marloth Reserve $\pm 100 \mathrm{~m}$ from Glenstroom, 212 m, (-CD), 9 Oct. 2007, Turner et al. s.n. (NBG).

17. Ixia collina Goldblatt \& Snijman in South African Journal of Botany 51: 68 (1985). Type: South Africa, [Western Cape], Aan de Doorns, SW of Worcester, Farm Alfalfa, Snijman 721 (NBG, holo!; MO!, PRE!, S!, iso.).

Plants $500-900 \mathrm{~mm}$ high, stem sheathed below by membranous cataphylls, usually 2-3-branched, branches held at right angles to main axis, ascending distally, subtended by short, acute bracts and prophylls. Corm

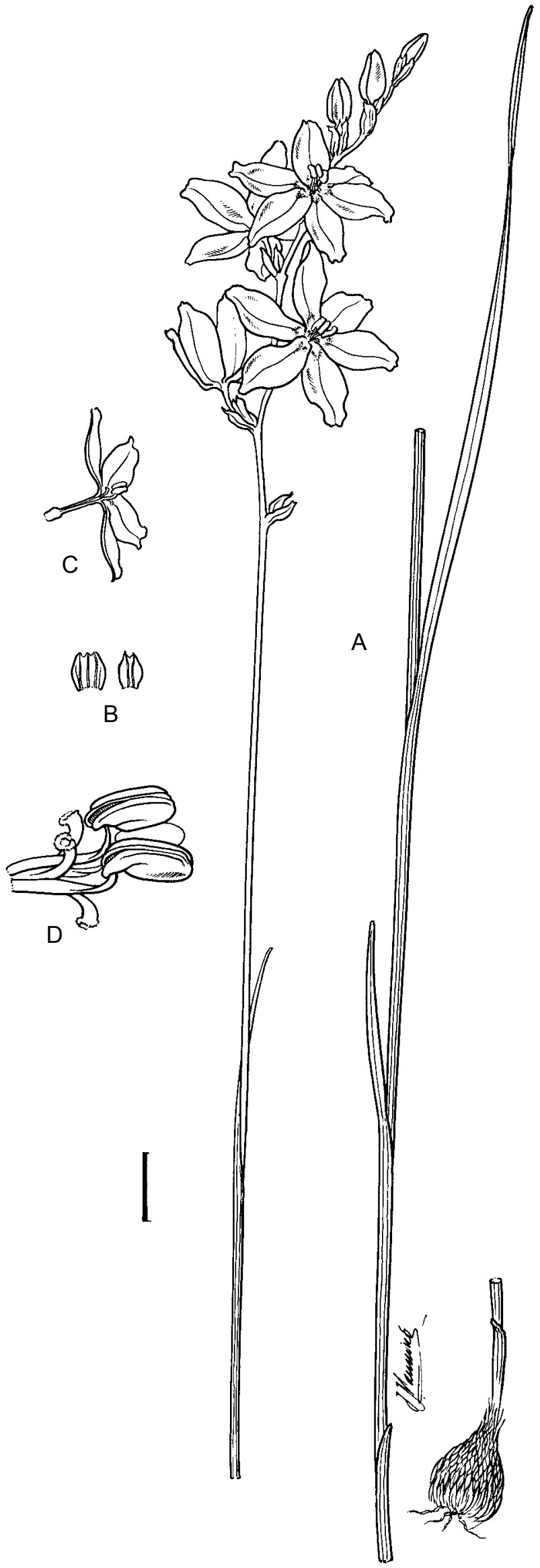

FIGURE 11.-Ixia simulans, Goldblatt \& Porter 12946 (NBG). A, flowering plant; B, outer (left) and inner (right) bract; $\mathrm{C}$, half flower; D, stamens and style branches, side view. Scale bar: 10 mm. Artist: John Manning. 
globose, 7-12 mm diam., tunics of medium-textured fibres, often with cormlets at base. Leaves 3 or 4, lower 2 or 3 with sublinear to narrowly sword-shaped blades, $\pm 1 / 2$ as long as stem, 4-8 mm wide, main vein moderately thickened, uppermost leaf sheathing lower half of stem. Spike flexuose, 7-16-flowered, lateral spikes with fewer flowers; bracts membranous, translucent, 4.5-7.0 $\mathrm{mm}$ long, outer with 3 prominent, purple veins, 3- or 5-toothed, inner 2-veined and 2-toothed. Flowers zygomorphic, half nodding, pink, white to yellow edged deep pink at tepal bases, sweetly scented, perianth tube filiform, $\pm 5 \mathrm{~mm}$ long, expanded in upper $0.5 \mathrm{~mm}$, tepals subequal, ovate, \pm obtuse, $9-12 \times \pm 5 \mathrm{~mm}$. Stamens unilateral, \pm horizontal, inserted at mouth of filiform part of tube, filaments $\pm 3 \mathrm{~mm}$ long, filiform below, curved at right angles in upper $1 \mathrm{~mm}$ and becoming flattened and as wide as anthers, anthers $\pm 3 \mathrm{~mm}$ long, oblong, yellow, thecae acute and recurved near base, dehiscing incompletely from base. Style dividing at base of filaments, style branches $\pm 2.5 \mathrm{~mm}$ long, tubular, falcate, bifid at apex, stigmatic apically. Flowering time: late-Aug.-mid Sept.

Distribution and habitat: Ixia collina is a narrow endemic of the mid Breede River Valley, its only known locality the Farm Alfalfa near Aan de Doorns south of Worcester (Figure 8). Plants grow on the southern slopes of low clay hills above the Breede River flood plain and adjacent to cultivated land. With so narrow a range Raimondo et al. (2009) regard the species as endangered (EN) and we agree. We recommend efforts be made to locate additional populations but there is little doubt that I. collina is extremely rare.

Diagnosis and relationships: Ixia collina is easily distinguished from other members of ser. Dichone by the unusual branching pattern: the relatively short branches extend outward horizontally and curve upward distally as well as by an unusual floral feature. The filaments are unique in the section in being filiform below, curved at right angles in the distal $1 \mathrm{~mm}$ and broadened so that they are as wide as the anthers.

\section{Additional specimen}

WESTERN CAPE.-3419 (Worcester): Aan de Doorns, SW of Worcester, Scherpenheuwel, on Farm Reiersrus, (-DC), Bruwer sub Walters 750 (NBG)

\section{EXCLUDED SPECIES}

Ixia retusa Salisb., Prodromus stirpium in horto ad Chapel Allerton vigentium: 35 (1796). The identity of this species has remained a mystery as the description is inadequate to identify the plant (De Vos 1999) and no type is known. Lewis (1962) suggested I. retusa might be $I$. stricta but with a query. Ker Gawler (in Sims 1801; 1803) associated the name with what he called Ixia polystachya (actually I. scillaris, thus not the same as Linnaeus's species) [see extensive discussion under Taxonomic History]. Although we suspect that I. retusa is a member of sect. Dichone, it is impossible to tell which species and the name must be rejected. Likewise, Klatt's combination, Watsonia retusa (Salisb.) Klatt is rejected (see additional discussion under Ixia stricta).

\section{ACKNOWLEDGEMENTS}

Support for this study by grants 7316-02, 7799-05, and 8248-07 from the National Geographic Society is gratefully acknowledged. Collecting permits were provided by the Nature Conservation authorities of Northern Cape and Western Cape, South Africa. We thank Ingrid Nänni, Elizabeth Parker, and Lendon Porter for their assistance and companionship in the field; Roy Gereau for advice with nomenclatural queries; Clare Archer, South African National Herbarium, Pretoria for help with several questions; Mary Stiffler, Research Librarian, Missouri Botanical Garden, for providing copies of needed literature; Sharon Bodine for help with herbarium searches. We also thank the curators of the following herbaria for allowing us access to their collections or for the loan of material for extended study: BOL, K, MO, NBG, PRE, and SAM (acronyms following Holmgren et al. 1990)

\section{REFERENCES}

ANDREWS, H. 1797. Ixia reflexa. Reflex flowered Ixia. The botanist's repository 1: t. 14.

ANDREWS, H. 1800. Ixia polystachya var. incarnata. The botanist's repository 2: t. 128 .

ANDREWS, H. 1801. Recensiae plantarum. London, J. White.

BAKER, J.G. 1876. New species of Ixieae. Journal of Botany (London) 5: 236-239.

BAKER, J.G. 1877 [as 1878]. Systema iridearum. Journal of the Linnean Society, Botany 16: 61-180.

BAKER, J.G. 1892. Handbook of the Irideae. Bell, London.

BAKER, J.G. 1896. Irideae. In W.T. Thiselton-Dyer (ed.), Flora capensis 6: 7-171. Reeve, London.

BROWN, N.E. 1929. The Iridaceae of Burman's Florae capensis prodromus. [Royal Botanic Gardens, Kew] Bulletin of Miscellaneous Information 1929: 129-137.

BURMAN, N.L. 1768. Prodromus florae capensis. Cornelius Haek, Amsterdam.

DE VOS, M.P. 1982. The African genus Tritonia Ker-Gawler 1. Journal of South African Botany 48: 105-163.

DE VOS, M.P. 1999. Ixia. In M.P. de Vos \& P. Goldblatt, Flora of southern Africa 7, part 2, fascicle 1: 3-87.

ECKLON, C.F. 1827. Topographisches Verzeichniss der Pflanzensammlung von C.F. Ecklon. Esslingen.

GOLDBLATT, P. 1971a. Cytological and morphological studies in the southern African Iridaceae. Journal of South African Botany 37: $317-460$.

GOLDBLATT, P. 1971b. A new species of Gladiolus and some nomenclatural changes in the Iridaceae. Journal of South African Botany 37: 229-236.

GOLDBLATT, P. 1985. Revision of the southern African genus Geissorhiza (Iridaceae: Ixioideae). Annals of the Missouri Botanical Garden 72: 277-447.

GOLDBLATT, P. \& MANNING, J.C. 1999. New species of Sparaxis and Ixia (Iridaceae: Ixioideae) from Western Cape, South Africa, and taxonomic notes on Ixia and Gladiolus. Bothalia 29: 59-63.

GOLDBLATT, P. \& MANNING, J.C. 2006. Notes on the systematics and nomenclature of Tritonia (Iridaceae: Crocoideae). Bothalia 36: 57-61.

GOLDBLATT, P. \& MANNING, J.C. 2007. Pollination of Romulea syringodeoflora (Iridaceae: Crocoideae) by a long-proboscid fly, Prosoeca sp. (Diptera: Nemestrinidae). South African Journal of Botany 73: 56-59.

GOLDBLATT, P. \& MANNING, J.C. 2011. Systematics of the southern African genus Ixia (Iridaceae): 3. Sections Hyalis and Morphixia. Bothalia 41: 83-134.

GOLDBLATT, P., BARI, A. \& MANNING J.C. 1991. Sulcus and operculum structure in the pollen grains of Iridaceae subfamily Ixioideae. Annals of the Missouri Botanical Garden 78: 950-961.

GOLDBLATT, P., BERNHARDT, P. \& MANNING, J.C. 1998. Pollination of petaloid geophytes by monkey beetles (Scarabaeidae: Ruteliinae: Hopliini) in southern Africa. Annals of the Missouri Botanical Garden 85: 215-230. 
GOLDBLATT, P., BERNHARDT, P. \& MANNING, J.C. 2000. Adaptive radiation of pollination mechanisms in Ixia (Iridaceae: Crocoideae). Annals of the Missouri Botanical Garden 87: 564-577.

GOLDBLATT, P., DAVIES, T.J., MANNING, J.C., VAN DER BANK, M. \& SAVOLAINEN, V. 2006. Phylogeny of Iridaceae subfamily Crocoideae based on combined multigene plastid DNA analysis. Aliso 22: 399-411.

GOLDBLATT, P., RODRIGUEZ, A., POWELL, M.P., DAVIES, T.J., MANNING, J.C., VAN DER BANK, M. \& SAVOLAINEN, V. 2008. Iridaceae 'Out of Australasia'? Phylogeny, biogeography, and divergence time based on plastid DNA sequences. Systematic Botany 33: 495-508.

GOLDBLATT, P. \& SNIJMAN, D. 1985. New species and notes on the southern African genus Ixia (Iridaceae). South African Journal of Botany 51: 66-70.

GUNN, M. \& CODD, L.E. 1981. Botanical exploration of southern Africa. Balkema, Cape Town.

HOLMGREN, P.K., HOLMGREN, N.H. \& BARNETT, L.C. 1990. Index Herbariorum. Part. 1: The Herbaria of the World. New York Botanical Garden, New York.

JACQUIN, N.J. 1792. Ixia polystachya. Icones plantarum rariorum 2(9): t. 275. Wappler, Vienna

KER GAWLER, J. 1802. Ixia maculata, var $\gamma$, viridis, green-stained ixia. Curtis's Botanical Magazine 16: t. 549.

KER GAWLER, J. 1803. Ixia polystachia. Lily of the valley-scented ixia. Curtis's Botanical Magazine 17: t. 629.

KER GAWLER, J. 1827. Genera Iridearum. De Mat, Brussels.

KLATT, F.W. 1882. Ergänzungen und Berichtigungen zu Baker's Systema Iridacearum. Abhandlungen der naturforschenden Gesellschaft zu Halle 15: 44-404.

KLATT, F.W. 1894. Iridaceae. Pp. 143-230 in T.A. Durand \& H. Schinz, Conspectus florae africae 5. De Mat, Brussels.

LEWIS, G.J. 1934. Ixia trifolia. Flowering Plants of South Africa 14: t. 543 .
LEWIS, G. J. 1954. Some aspects of the morphology, phylogeny and taxonomy of the South African Iridaceae. Annals of the South African Museum 40: 15-113.

LEWIS, J. 1962. South African Iridaceae: the genus Ixia. Journal of South African Botany 27: 45-195.

LINNAEUS, C. 1753. Species plantarum. Salvius, Stockholm.

LINNAEUS, C. 1762. Species plantarum, edn. 2, 1. Salvius, Stockholm.

LINNAEUS, C. (fil). 1782 [as 1781]. Supplementum plantarum. Orphanotropheus, Brunswick.

MANNING, J.C. \& GOLDBLATT, P. 2006. New species of Iridaceae from the Hantam-Roggeveld centre of endemism and the Bokkeveld, Northern Cape, South Africa. Bothalia 36: 139-145.

MANNING, J.C., GOLDBLATT, P. \& SNIJMAN, D. 2002. The color encyclopedia of Cape bulbs. Timber Press, Portland, OR.

RAIMONDO, D., VON STADEN, L., FODEN, W., VICTOR, J.E., HELME, N.A., TURNER, R.C., KAMUNDI, D.A. \& MANYAMA, P.A. (eds). 2009. Red List of South African Plants. Strelitzia 25. South African National Biodiversity Institute, Pretoria.

ROEMER, J.J. \& SCHULTES, J.A. 1817. Systema vegetabilium. J. G. Cotta, Stuttgart.

SALISBURY, R. 1796. Prodromus stirpium in horto ad Chapel Allerton vigentium. London.

SALISBURY, R. 1812. On the cultivation of rare plants, etc. Transactions of the Horticultural Society, London 1: 261-366.

SIMS, G. 1801. Ixia scillaris, var. latifolia (a). Squill-flowered Ixia.Broad-leaved variety. Curtis's Botanical Magazine 15: t. 542.

STAFLEU, F.A. \& COWAN, R.S. 1979. Taxonomic Literature, vol. 2. W. Junk, The Hague.

THUNBERG, C.P. 1783. Dissertatio de Ixia. Edman, Uppsala.

VAN ROYEN, A. 1740. Florae leydensis prodromus. Luchtmans, Leiden. 